Chicago-Kent College of Law

Scholarly Commons @ IIT Chicago-Kent College of Law

4-1-2013

\title{
The Dark Side of Town: The Social Capital Revolution in Residential Property
}

Stephanie M. Stern

IIT Chicago-Kent College of Law, sstern@kentlaw.iit.edu

Follow this and additional works at: https://scholarship.kentlaw.iit.edu/fac_schol

Part of the Property Law and Real Estate Commons

\section{Recommended Citation}

Stephanie M. Stern, The Dark Side of Town: The Social Capital Revolution in Residential Property, 99 Va. L. Rev. 811 (2013).

Available at: https://scholarship.kentlaw.iit.edu/fac_schol/770

This Article is brought to you for free and open access by the Faculty Scholarship at Scholarly Commons @ IIT Chicago-Kent College of Law. It has been accepted for inclusion in All Faculty Scholarship by an authorized administrator of Scholarly Commons @ IIT Chicago-Kent College of Law. For more information, please contact jwenger@kentlaw.iit.edu, ebarney@kentlaw.iit.edu. 


\section{THE DARK SIDE OF TOWN: THE SOCIAL CAPITAL} REVOLUTION IN RESIDENTIAL PROPERTY LAW

\section{Stephanie M. Stern ${ }^{*}$}

Social capital has pervaded property law, with scholars and policymakers advocating laws and property arrangements to promote social capital and relying on social capital to devolve property governance from legal institutions to resident groups. This Article challenges the prevailing view of social capital's salutary effects with a more skeptical account that examines the dark side of residential social capital-its capacity to effectuate local factions and to promote restraints and inegalitarianism that close off property. I introduce a set of claims about social capital's dark side in residential property and explore these points through the examples of local racial purging, land cartels, and residential self-governance. First, contrary to the assumption of a social capital deficit, residential racial segregation and land cartelization, perhaps the deepest imprints on the American property landscape today, suggest an abundance of local social capital and possible unintended consequences of interventions to build social capital. Second, "governing by social capital," or relying on social capital for property self-governance, may empower factions, breed conflict, and increase the demand for residential homogeneity as a proxy for cooperation. In light of the mixed evidence for social capital's benefits and its sizeable dark side, the more pressing and productive role for property law is not to promote social capital, but to address its negative spillovers and illiberal effects.

INTRODUCTION 812

I. The Social CAPital Revolution In PRoperty LaW....................8 821

A. Social Capital in Property Theory and Policy.

\footnotetext{
* Irving S. Ribicoff Visiting Associate Professor of Law, Yale Law School (fall 2012) and Associate Professor of Law, Chicago-Kent College of Law. For their generous and insightful comments, I would like to thank Carol Rose, Bob Ellickson, Amy Kapczynski, Bruce Ackerman, Claire Priest, Lior Strahilevitz, Cherie Metcalf, Larissa Katz, Bethany Berger, Riva Siegel, Rick Hills, Peter Schuck, Amalia Kessler, Katrina Wyman, Richard Squire, Kathy Baker, Steven Durlauf, Frederic Bloom, Helen Norton, Tom Gaylord, Annie Decker, the participants of the Yale faculty workshop, the NYU Colloquium on the Law, Economics, and Politics of Urban Affairs, the Queen's University Osler Lecture, the Fordham Urban Law Journal Symposium, the University of Connecticut faculty workshop, and the Emory University School of Law faculty colloquium.
} 
B. Social Science Evidence: The Case for Social Capital ........... 830

II. The Dark Side Of Residential Social CaPital .......................... 835

A. Sundown Towns: Social Capital, Racial Segregation, and Bad Norm Lock-In.....

B. Exclusionary Zoning: Social Capital and Local Land Cartels

III. RESIDENTIAL PROPERTY: GOVERNING THROUGH SOCIAL

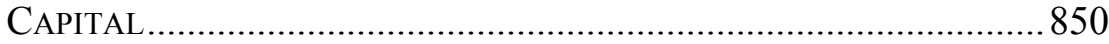

A. Assessing Neighborhood Direct Democracy and Block Associations

B. Common Interest Communities: Condominiums, Co-ops, and Homeowners Associations

IV. Residential Norms, Social CAPITAL, AND SMALl Republic

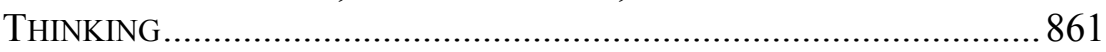

V. BEYOND GEMEINSCHAFT PROPERTY .............................................. 865

A. Political Organizing, Low-Income Communities, and Social Capital.

B. The Social Production of Neighborhood and Individual Capacity 871

C. Alternatives for Generalized Solidarity.

\section{INTRODUCTION}

TN 2007, accompanied by a firestorm of publicity, Robert Putnam announced that residential racial diversity causes declines in social capital. ${ }^{1}$ Social capital is a prominent theory, popularized by Putnam, of the aggregate value of citizen participation in associations and organizations, social ties and networks, civic engagement, trust, and norms of reciprocity. ${ }^{2}$ In a study of forty-one U.S. communities, Putnam found that people living in racially diverse communities were less likely to work on a community project or volunteer, less likely to expect others to cooperate to solve collective problems, reported lower trust in others, had fewer close friendship ties, expressed less confidence in local gov-

\footnotetext{
${ }^{1}$ See Robert D. Putnam, E. Pluribus Unum: Diversity and Community in the Twenty-first Century, 30 Scandinavian Pol. Stud. 137, 144, 149-50 (2007).

${ }^{2}$ See Robert D. Putnam, Bowling Alone 19 (2000).
} 
ernment, and registered to vote less frequently. ${ }^{3}$ Most provocatively, Putnam found a strong "hunker[ing] down" effect, contrary to both the constrict and contact hypotheses of integration, where racial diversity caused residents of diverse communities to withdraw from social and civic life and to report lower trust in members of other races and their own race. ${ }^{4}$

Unsurprisingly (to all but Robert Putnam, it seems), his research provoked a torrent of political commentary and academic response. Conservative commentators argued that the findings called into question the value of racial mixing, headlines trumpeted the conclusion that "greater diversity equals more misery," and Putnam's research featured in a recent amicus brief as evidence against the value of affirmative action in college admissions. ${ }^{6}$ Sociologists and economists reanalyzed Putnam's data and conducted their own empirical studies to assess his findings (these studies indicate that the diversity decrement is statistically significant, but small). ${ }^{7}$ Legal scholars accepted, albeit unhappily, the conclusion that racial diversity diminishes local social capital. ${ }^{8}$

\footnotetext{
${ }^{3}$ After controlling for a host of variables at both the census-tract and individual level, including age, ethnicity, education, affluence/poverty, language, residential mobility, citizenship, commuting time, homeownership, region, gender, financial satisfaction, work hours, crime, population density, and income inequality, there were reductions in social capital as high as thirty to fifty percent for the most diverse communities as compared to the least diverse. See Putnam, supra note 1, at 148, 151-52.

${ }^{4}$ See id. at $147-49$.

${ }^{5}$ Ilana Mercer, Op-Ed., Greater Diversity Equals More Misery, Orange County Reg., July 22, 2007, available at http://www.ocregister.com/opinion/putnam-59065-diversity-social. html ("When an academic 'discovers' what ordinary mortals have known for eons, it's called science.").

${ }^{6}$ See Brief of Abigail Thernstrom et al. as Amici Curiae in Support of Petitioners at 1113, Fisher v. Univ. of Tex., No. 11-345 (May 29, 2012) (arguing that Putnam's research reveals social harms that do not support contact theory and the claimed benefits to diversity); see also David Brooks, Op-Ed., The End of Integration, N.Y. Times, July 6, 2007, at A15; Georgie Anne Geyer, The Case Against Multiculturalism, Free Republic (Aug. 14, 2007, 2:02 PM), http://www.freerepublic.com/focus/f-news/1881086/posts; Michael Jonas, The Downside of Diversity, Bos. Globe, Aug. 5, 2007, at D1, D3 (describing reaction of conservative think tank the Manhattan Institute and describing Putnam's "inconvenient truth"). But see Brief of Dr. Robert D. Putnam as Amicus Curiae in Support of Respondents at 11, Fisher v. Univ. of Tex., No. 11-345 (Aug. 13, 2012) (claiming long-term benefits of diversity not captured by his recent data).

${ }^{7}$ See infra note 159 .

${ }^{8}$ See Raymond H. Brescia, Capital in Chaos: The Subprime Mortgage Crisis and the Social Capital Response, 56 Clev. St. L. Rev. 271, 280 (2008) [hereinafter Brescia, Capital] (citing Putnam's work on racial and ethnic diversity and stating that "[i]n more heterogeneous communities, social capital is harder to develop"); Robert C. Ellickson, The False Prom-
} 
Curiously, in the handwringing about the harms to social capital from diversity, no one questioned whether the problem was social capital itself. From a property scholar's perspective, one plausible interpretation of the correlation between high social capital and low diversity is that high social capital reduces the costs of excluding minorities (that is, the non-dominant race in a community) and maintaining racial homogeneity. ${ }^{9}$ Holding preferences for racial homogeneity constant and positive, there may be reverse causation: high social capital, in the form of close social networks and strong tastes for organizational participation and voluntary action, may facilitate community organizing to exclude by race or class through both informal and legal mechanisms. ${ }^{10}$ The motivation for exclusion may be preferences for homogeneity, increased property values from exclusionary land use policies, or in predominantly minority, lower-income areas, concerns that white gentrification will make housing unaffordable. Conversely, low social capital may make it difficult for residents to organize to exclude and may result in greater racial fractionalization.

The point of this discussion is not to establish a definitive, exclusive, or even likely explanation for the finding of a negative correlation between diversity and social capital. There are multiple possible explanations and potential omitted variables in that research and any causal role

ise of the Mixed-Income Housing Project, 57 UCLA L. Rev. 983, 1014-15 (2010) [hereinafter Ellickson, Mixed-Income Housing]; Nicole Stelle Garnett, The People Paradox, 2012 U. Ill. L. Rev. 43, 43-52 (2012); James A. Kushner, Urban Neighborhood Regeneration and the Phases of Community Evolution after World War II in the United States, 41 Ind. L. Rev. 575,600 (2008) (noting that "the politically correct rhetoric that we celebrate diversity fails to reflect the Nation's beliefs"); Florence Wagman Roisman, Living Together: Ending Racial Discrimination and Segregation in Housing, 41 Ind. L. Rev. 507, 519 (2008) (describing scholarly and popular reactions to Putnam's research); Peter Schuck, In Diversity We (Sorta) Trust, Am. Law., Dec. 2007, at 83-84 (describing Putnam's research as "very important in providing a firm empirical confirmation of what many close students of diversity thought we already knew").

${ }^{9}$ High social capital could be randomly distributed or more likely endogenously related to other community features, or the result of high social capital types self-selecting into communities with like-minded residents. In practice, it is likely that this effect is strongest in predominantly white communities as middle and upper class whites generally tout high social capital scores - a fact which raises the question of an omitted variable effect. See infra Section I.B.

${ }^{10}$ For example, exclusionary zoning may work most effectively in communities with high social capital that cannot only zone ex ante but hold the line against developers' efforts to circumvent zoning. See infra Section II.B. 
for social capital may be partial. ${ }^{11}$ Instead, the aim of this thought experiment is to illustrate how social capital can close off residential property by reducing supply or constraining who may access the supply. Rather than worrying about diversity's harms to social capital, perhaps we should be concerned about social capital's harms to diversity — and to residential property.

Social capital is an influential theory of the value of participation in organizations, social ties and networks, civic engagement and voting, trust, and norms of reciprocity to economic and political flourishing. Putnam analogizes social capital to more traditional forms of capital: "Whereas physical capital refers to physical objects and human capital refers to properties of individuals, social capital refers to connections among individuals - social networks and the norms of reciprocity and trustworthiness that arise from them." "2 Social capital exponents claim that social capital operates as a group-level positive externality that promotes national and local economic growth, better health and education outcomes, and, more tautologically, collective action and democratic participation. ${ }^{13}$ While not blind to the potential ill effects and negative externalities of social capital, Putnam and other social capitalists advance social capital as a positive public good and an indicator of community prosperity. ${ }^{14}$ Local social capital is principally a theory of social cohesion, or bonding capital, and the capacity of residential groups to produce public goods without the guiding hand of state or Keynesian intervention - $\mathrm{a}$ social science-infused theory of residential gemeinschaft. ${ }^{15}$

\footnotetext{
${ }^{11}$ For example, low social capital in racially diverse areas, which are disproportionately low-income, may also reflect resident discontent with economic entrapment in low-status or non-white neighborhoods. Whites in diverse communities may express greater distrust of blacks or other minorities because their prejudice is more salient in a diverse community, and they may express greater distrust of other whites because of their frustration with their living situation. Also, selection into diverse communities, which are often of lower-status and wealth, may reflect lower ex ante social capital that limits access to information about housing opportunities and reduces capacity to handle the stresses of relocation.

${ }^{12}$ See Putnam, supra note 2 , at 19.

${ }^{13}$ See id. at $289-90$.

${ }^{14}$ See Elinor Ostrom, Governing the Commons: The Evolution of Institutions for Collective Action 36 (1990); The Saguaro Seminar: Civic Engagement in America, Harvard Kennedy School, http://www.hks.harvard.edu/saguaro (last visited Apr. 9, 2013) (describing social capital policy initiatives, community-building, and research).

${ }^{15}$ Unlike Putnam's, other sociological theories of social capital focus on status and power differences in their social capital construct and analyses. See, e.g., James S. Coleman, Foundations of Social Theory 300-18 (1990). Pierre Bourdieu, an earlier theorist, conceptualized
} 
In the past decade, there has been a remarkable ascendance of social capital theory in property scholarship and law, a trend that has not been examined to date. ${ }^{16}$ The underspecified and encompassing nature of social capital makes it simultaneously attractive to property scholars and dangerous to theory - part of the appeal of social capital is that it is capacious enough to justify a breadth of agendas. ${ }^{17}$ Property scholars have become enthusiastic social capitalists, ${ }^{18}$ writing about how home mortgage reform, land use law, homeownership, block-level governance, school finance, process restrictions on eminent domain, and laws governing common interest communities can promote, or capitalize upon, social capital. ${ }^{19}$ Social capital has also had far-ranging influence over

social capital as an individual asset generated by not only personal and group ties, but also institutionalized relationships, impersonal networks of material or cultural exchange, and class-based social status distinctions. See Pierre Bourdieu, The Forms of Capital, in Handbook of Theory and Research for the Sociology of Education 241, 248-49 (John G. Richardson ed., 1986).

${ }^{16}$ Beyond property, legal articles in fields ranging from federalism to family law have considered how law can increase social capital. See, e.g., Jason Mazzone, The Social Capital Argument for Federalism, 11 S. Cal. Interdisc. L.J. 27, 42 (2001); Jason Mazzone, Towards a Social Capital Theory of Law: Lessons from Collaborative Reproduction, 39 Santa Clara L. Rev. 1, 60-75 (1998) (arguing that family law should maintain family, rather than community, social capital); Richard H. Pildes, The Destruction of Social Capital Through Law, 144 U. Pa. L. Rev. 2055, 2063 (1996).

${ }^{17}$ For example, William Fischel maintains that local public schools, unlike voucher schools, enhance the flow of information and collective action by building social capital among geographically proximate parents, while Margaret Brinig and Nicole Garnett contend that extending voucher-based education to private Catholic schools increases social capital and collective efficacy in areas surrounding parish schools. See Margaret F. Brinig \& Nicole Stelle Garnett, Catholic Schools, Urban Neighborhoods, and Education Reform, 85 Notre Dame L. Rev. 887, 925-28 (2010); William A. Fischel, Why Voters Veto Vouchers: Public Schools and Community-Specific Social Capital, 7 Econ. of Governance 109, 113-16 (2006).

${ }^{18}$ I use the term social capitalist descriptively to refer to exponents of social capital, not to suggest a perfect parallel with economic capitalism or capital.

${ }^{19}$ See, e.g., Lisa T. Alexander, Hip-Hop and Housing: Revisiting Culture, Urban Space, Power, and Law, 63 Hastings L.J. 803, 825-26 (2012); Brescia, Capital, supra note 8, at 273; Robert C. Ellickson, New Institutions for Old Neighborhoods, 48 Duke L.J. 75, 83-84 (1998) [hereinafter Ellickson, New Institutions]; Sheila R. Foster, The City as an Ecological Space: Social Capital and Urban Land Use, 82 Notre Dame L. Rev. 527, 530-43 (2006) (exploring how local land use law affects urban social capital); Paula A. Franzese, Does It Take a Village? Privatization, Patterns of Restrictiveness and the Demise of Community, 47 Vill. L. Rev. 553, 588 (2002) (arguing that developer-created laws governing common interest communities and common regulatory practices of homeowners associations chill needed social capital); Asmara Tekle Johnson, Correcting for Kelo: Social Capital Impact Assessments and the Re-Balancing of Power Between "Desperate" Cities, Corporate Interests, and the 
property policy, with local zoning and planning for social capital, federal Hope VI funding for low-income housing requiring social capitalenhancing design features, homeownership subsidies justified on social capital grounds, experiments with "neighborhood direct democracy" and block associations, and World Bank development policy to build social capital. ${ }^{20}$ Nobel Prize winner Elinor Ostrom has been an influential proponent of the importance of social capital to avoid tragedies of the commons and enable successful community governance of natural resources. ${ }^{21}$

There are two threads to the theoretical account of social capital in the property scholarship. First, property law should promote social capital in residential communities on the theory that robust social capital benefits local institutions and residents, and, in some accounts, spills over to advantage national democracy and economic growth. Property law can affirmatively build social capital by promoting interpersonal interaction, mutual reliance, or residential stability - at which point law should recede. ${ }^{22}$ In some accounts, the omission or downscaling of formal law encourages cooperation and lessens the risk that ham-handed laws will suffocate the delicate shoots of growing social capital. ${ }^{23}$ Second, and somewhat circularly, social capital fuels successful property institutions and enables devolution of governance and public and private goods provision to resident groups. ${ }^{24}$ The unifying strand of these narratives is that social capital, properly nourished, produces positive externalities in an acceptably, if not perfectly, egalitarian manner and decreases the need for legal institutions. Following Putnam, property scholars take a func-

Average Joe, 16 Cornell J.L. \& Pub. Pol'y 187, 191 (2006) (proposing a Social Capital Impact Assessment prior to a taking).

${ }^{20}$ See Matthew F. Filner, The Limits of Participatory Empowerment: Assessing the Minneapolis Neighborhood Revitalization Program, 38 St. \& Loc. Gov't Rev. 67, 67-70 (2006). See generally infra Section I.A.

${ }^{21}$ See Elinor Ostrom, Social Capital: A Fad or a Fundamental Concept?, in Social Capital: A Multifaceted Perspective 172, 173, 195-98 (Partha Dasgupta \& Ismail Serageldin eds., 2000).

${ }^{22}$ See, e.g., Robert C. Ellickson, Order Without Law: How Neighbors Settle Disputes 270-72 (1994) [hereinafter Ellickson, Order] (describing how law can promote relationships and repeat play necessary for informal social control); Franzese, supra note 19, at 591-92 (noting that social capital can relieve formal institutions of burdens best left to informal networks).

${ }^{23}$ See Franzese, supra note 19, at 588; Ostrom, supra note 21, at 182.

${ }^{24}$ See Ellickson, New Institutions, supra note 19, at 83-84; Franzese, supra note 19, at 589-90. 
tionalist (and tautological) approach: social capital is present when positive effects accrue. ${ }^{25}$ Notably, there appears to be no upward bound on the amount of social capital deemed optimal for communities. The implicit message of social capital is more is always better.

In this Article, I advance an account of the dark side of social capital in residential property. My critique of social capital focuses on "bonding capital" (that is, strong social ties, thick trust, and shared norms within cohesive communities) as the far more ubiquitous and theoretically central form of social capital. I employ the terms social capital and bonding capital interchangeably throughout the paper. Social capital is an important factor effectuating, and sometimes creating, local factions with interests contrary to the public interest and the rights of other citizens that so concerned Madison. ${ }^{26}$ Networks, reciprocity, trust, tastes for participation, and social ties facilitate collusion to restrain residential property supply and to act on pre-existing preferences for illiberal exclusion. ${ }^{27}$ Social capital can also create or heighten such preferences as collective action escalates individual commitments and dense, reciprocal ties lock in bad norms and stifle dissent.

The enthusiasm for social capital has also obscured tradeoffs in the devolution of property governance to residential groups. Governing through social capital by resident groups can deliver cost-savings and benefits of local knowledge, but it may also directly empower factions, confine social exchange, and increase the demand for homogeneity. ${ }^{28}$ Devolving governance and public goods provision to residents ratchets up the importance of cooperation in the face of inflated, and pervasive,

\footnotetext{
${ }^{25}$ Putnam's fourteen-item composite measure does not adequately separate the determinants of social capital from its consequences. Other definitions of social capital are also riddled with conceptual ambiguity and circularity. See, e.g., Michael Woolcock, The Place of Social Capital in Understanding Social and Economic Outcomes, 2 Canadian J. Pol'y Res. 11, 13 (2001) (giving a circular definition of social capital as "the norms and networks that facilitate collective action"); see also Alejandro Portes, Social Capital: Its Origins and Applications in Modern Sociology, 24 Ann. Rev. Soc. 1, 19 (1998) (stating that social capital "leads to positive outcomes, such as economic development and less crime, and its existence is inferred from the same outcomes").

${ }^{26}$ I thank Bruce Ackerman for his helpful insights and comments on factions and social capital.

${ }^{27}$ See, e.g., James DeFilippis, The Myth of Social Capital in Community Development, 12 Housing Pol'y Debate 781, 792 (2001) (stating that ethnic enclaves "completely close[] off the market, and access to the market, to anyone who is not part of the ethnic group creating the enclave").

${ }^{28}$ This happens in formal institutions and organizations as well, but subject to thicker legal constraints.
} 
perceptions that similar others cooperate best (at times, promoting social capital has verged perilously close to engineering residential racial homogeneity). Social-capital mediated governance may also encourage illiberal internal distributions of property and governance roles as classand characteristic-based social status serves as a quick and dirty allocation device to reduce the overwhelming coordination costs of collective action. $^{29}$

Social capital has masked these issues in its sunny language of sociability and the promise that sufficient social capital self-corrects its own harms to a substantial degree. An antidote to harmful private-regarding norms and factions is to build more expansive and encompassing communities of interest and mutual obligation. Social capital claims this solution in the form of "bridging ties" across social and geographic divides which ostensibly inculcate public-regarding orientations and tolerance of diversity (and if this does not occur it is because more social capital must be fostered). ${ }^{30}$ Yet, we know little about how to build bridging ties in a way that will prevent or mitigate negative externalities from local social capital. And there is no evidence that diffusely constructed social capital, if achieved, will reliably trump tighter-knit bonding social capital, or that bridging ties will not morph into bonding capital.

A question remains: are the problems I describe due to social capital or bad norms? The answer is both. The ill effects of social capital derive most frequently from its instrumental capacity to effectuate bad norms and socially harmful motivations. In the residential context, Americans' excessive, undiversified investment in homeownership does not reliably inculcate extra-local civic virtue, and the norms attached to residential property imperfectly and inconsistently address broader social obligations and public citizenship. ${ }^{31}$ Social capital can also produce bad norms in two ways. First, it can create socially harmful preferences through the process of cooperating in repeated, often ideologically binding interactions (the very promise of social capital). ${ }^{32}$ There is a wealth of evidence that forming or strengthening "in-groups" creates in-group favoritism,

\footnotetext{
${ }^{29}$ These points may underlie Carol Rose's critiques of non-egalitarianism in Ostrom's commons. See Carol M. Rose, Ostrom and the Lawyers: The Impact of Governing the Commons on the American Legal Academy, 5 Int'1 J. Commons 28, 44 (2011).

${ }^{30}$ See Putnam, supra note 2, at 22-24 (discussing bridging ties).

${ }^{31}$ See William Fischel, The Homevoter Hypothesis 10-20 (2001).

32 Another harm is from "downward leveling norms" in poor but solidaristic communities that impede individual economic advancement. See, e.g., Portes, supra note 25, at 17.
} 
biases beliefs in favor of the group's interests, and yields more extreme group action. ${ }^{33}$ Second, in my view, social capital reifies self-interested activity at the expense of broader public-regarding conceptions of the local resident-citizen role. Extra-local social obligations are less pressing, and the tradeoffs between group benefits and public harms less troubling, because local working-together yields national dividends.

In developed market economies with established legal institutions, relying on social capital to regulate residential property or sustain community-governed property institutions with thin legal frameworks may be a second-best solution. Rather than diminish the role of formal law, abundant social capital may increase the need for legal safeguards and, in some cases, the desirability of formal institutions. This is not to dismiss the work of Elinor Ostrom or Bob Ellickson, but rather to suggest that devolution from formal law and institutions to self-governing groups requires a fuller accounting of social capital's costs to residential life, property supply, and liberalism. Implicit in my account is also a skeptical assessment of the claimed benefits of cohesive social capital to residential communities. After almost three decades of research, we know little about how to promote or extract positive social capital through property law or residential configurations - many attempts at social capital engineering have been fumbling and ill-fated. ${ }^{34}$ There is a sense, undoubtedly correct, that social ties, informal cooperation, and altruism within parent groups, congregations, and other groups can have social value. However, it is a leap from these voluntary, organic examples of social capital —often subject to thicker constraints or occurring in areas where government non-involvement is pivotal to social or personal identity - to relying on social capital to devolve property governance or structure property law. Indeed, the recent enthusiasm for social capitalbuilding and informal micro-governance may be a step backward to closed and private-minded societies — what Ferdinand Tönnies described

\footnotetext{
${ }^{33}$ See, e.g., Leon Festinger, A Theory of Cognitive Dissonance 261-62 (1957); Irving L. Janis, Victims of Groupthink: A Psychological Study of Foreign-Policy Decisions and Fiascoes 10-13 (1972); Cass R. Sunstein, Going to Extremes: How Like Minds Unite and Divide $42-44$ (2009).

${ }^{34}$ See infra Section I.B. Other examples include urban renewal intended to create more socially healthy neighborhoods and mixed-use zoning to build social capital that instead appears to increase crime. See Robert J. Sampson \& Stephen W. Raudenbush, Systematic Social Observation of Public Spaces: A New Look at Disorder in Urban Neighborhoods, 105 Am. J. Soc. 603, 603-11 (1999).
} 
as gemeinschaft - that limit social exchange and sacrifice social progress and innovation for insularity. ${ }^{35}$

The Article proceeds as follows. Part I describes the rise of social capital theory in residential property law and considers the empirical case for social capital. Part II examines the dark side of residential social capital and the role of social capital in racial and economic segregation and land cartels. Part III argues that devolution to resident groups, or governing by social capital, can empower factions and increase the demand for residential homogeneity. To make my analysis more concrete, I assess proposals for neighborhood direct democracy programs, blocklevel associations, and legal reform of common interest communities. In Part IV, I conclude that residential norms and roles offer weak constraints against social capital's negative externalities. Part V considers the role of law with respect to social capital, offers preliminary thoughts on disaggregating social capital and the utility of its component parts, and addresses potential objections to my account. Because my analysis of the dark side of social capital follows from the underspecified construct of social capital, it is, inescapably, coarse-grained. If social capital, and correspondingly my account of its negative externalities, ultimately proves too vague or tautological, then perhaps we need to abandon social capital in property discourse.

\section{The Social Capital Revolution in Property LaW}

With his evocatively titled book Bowling Alone, Robert Putnam catapulted the theory of social capital to international fame. Social capital is the most recent iteration in a recurrent intellectual history of theories of solidaristic residential community - and laments of community lost. ${ }^{36}$ Putnam lauds diverse "bridging social capital," yet his work, and its uptake in the social science and legal literature, focuses on dense and insular "bonding capital" and its positive, causal role in local and national outcomes. ${ }^{37}$ The major measurement tools for social capital emphasize

\footnotetext{
${ }^{35}$ See Ferdinand Tönnies, Community and Civil Society 30, 48 (Jose Harris ed., 2001).

${ }^{36}$ See Robert J. Sampson, Great American City 44-45 (2011) (describing social capital as part of a longstanding intellectual history of theories of community lost and an "ideology of lament" that has impeded serious sociological inquiry).

${ }^{37}$ See Putnam, supra note 2, at 21-22; Citizendium Citizen Compendium, The Social Capital Foundation, http://www.socialcapital-foundation.org/TSCF/aboutus_citizendium.htm (last visited Apr. 9, 2013) (stating social capital is the "semantic equivalent to the spirit of community"); see also Robert D. Putnam, The Prosperous Community: Social Capital and
} 
tight-knittedness, social interaction, and participation of the type that often occurs in cohesive groups and communities. ${ }^{38}$ The generation and deployment of social capital lends itself to face-to-face interaction and organization at the local and sub-local level, where many theorists claim social capital plays its strongest role. ${ }^{39}$ Accordingly, my critique of social capital focuses on bonding capital. Bridging social capital is not immune from misuse (certain wars and political movements come to mind). However, on balance, bridging ties appear a less potent contributor to residential social ills and have some potential to reduce illiberal exclusion and anomie - points I return to in Part V.

The modern-day resonance of social capital has deep roots in nineteenth- and twentieth-century thought. Ferdinand Tönnies' 1887 theory of gemeinschaft elaborated the defining features of tight-knit, ideologically homogenous communities characterized by "natural will" and regulated informally by social bonds (gemeinschaft), and compared them to atomistic, diverse "associations" governed by rules and regulated competition (gesellschaft). ${ }^{40}$ Emile Durkheim's writing traced the evolution of societies from mechanistic, in-group solidarity to organic solidarity focused on the rights of individuals. ${ }^{41}$ Almost a century later, the Solidarity movement in Poland, rooted in a trade union that advocated sweeping social reform, declared the primacy of communal social relations in opposition to both state and market. ${ }^{42}$ Early discourse on social capital and community in America pursued similar themes of cohesiveness and engagement within local civil society. In 1835, de Tocqueville, now termed the "patron saint of contemporary social capitalists," posited

Public Life, 13 Am. Prospect 35, 36 (1993) ("Working together is easier in a community blessed with a substantial stock of social capital.").

${ }^{38}$ Over three-quarters of the items in Putnam's fourteen-item index capture, at least in part, local social cohesion. See Tristan Claridge, Measurement of Social Capital, Social Capital Research (Jan. 5, 2004), http://www.socialcapitalresearch.com/literature/operational isation/measurement.html. Alternative measures from other researchers and the World Bank similarly emphasize the context of the local community. See id.

${ }^{39}$ See infra Section I.A.

${ }^{40}$ Although Tönnies argued that gemeinschaft was the "childhood of humanity" and gesellschaft its maturity, this point has been largely overlooked in the subsequent incorporation of gemeinschaft into communitarian movements. See Steven Brint, Gemeinschaft Revisited: A Critique and Reconstruction of the Community Concept, 19 Soc. Theory 1, 2 (2001).

${ }^{41}$ See generally Emile Durkheim, The Division of Labor in Society (1893).

${ }^{42}$ See Brint, supra note 40 , at 1 . In recent years, the European Union has made social cohesion a goal, both across the EU and within residential communities. See Kath Hulse \& Wendy Stone, Social Cohesion, Social Capital and Social Exclusion, 28 Pol'y Stud. 109, 117 (2007). 
that the high level of associational activity in America fostered civil society and democracy. ${ }^{43}$ In 1916, state supervisor of rural schools L.J. Hanifan, later influential in the Social Center Movement, introduced the term social capital as the "goodwill, fellowship, mutual sympathy and social intercourse among a group of individuals and families who make up a social unit." ${ }^{44}$ Subsequently, the Community Studies Movement of the mid-twentieth century expanded on this conception of cohesion in residential communities and explored how participation and collective symbols create "place identity.", 45

\section{A. Social Capital in Property Theory and Policy}

In the past decade, social capital has ascended in property theory as an aim of property law and, somewhat circularly, as a prerequisite for successful property institutions and group self-governance. ${ }^{46}$ If the classic Lockean debate is whether property predates government (thus that government's purpose is to protect property), the question now is whether social capital precedes property, or the converse. The accounts in the property scholarship accept the validity of social capital and endorse its narrative of positive effects. ${ }^{47}$ They differ, however, in the ideological bases of their affinity for social capital and whether proposals focus in earnest on social capital, as is often the case, or instead deploy social capital to substantiate other agendas. As in the broader discourse, the uptake of social capital into property law has focused on bonding social capital accumulation through group cooperation and social cohesion. ${ }^{48}$ It is this sort of social cohesion, the refrain goes, that promotes

\footnotetext{
${ }^{43}$ Putnam, supra note 2, at 292. See generally Alexis de Tocqueville, Democracy in America (1945).

${ }^{44}$ See L.J. Hanifan, The Rural School Community Center, 67 Annals Am. Acad. Pol. \& Soc. Sci. 130, 130 (1916).

${ }^{45}$ Brint, supra note 40, at 5-6. For a classic work in the Community Studies Movement, see W. Lloyd Warner \& Paul S. Lunt, The Social Life of a Modern Community (1941).

${ }^{46}$ See, e.g., supra notes $22-24$.

${ }^{47}$ See supra notes 8 and 19.

${ }^{48}$ See, e.g., Ellickson, Mixed-Income Housing, supra note 8, at 1014-15; Ellickson, New Institutions, supra note 19, at 83-84; Franzese, supra note 19, at 588 (common interest communities); Ostrom, supra note 21 , at 176 (defining social capital in her analysis of property self-governance systems as "the shared knowledge, understandings, norms, rules, and expectations about patterns of interaction that groups of individuals bring to a recurrent activity"). Many accounts in sociology and political science also treat social capital as a theory of community. See, e.g., Brint, supra note 40, at 7 ("[S]ocial capital . . emphasizes the inter-
} 
effective property governance, non-state resolution of collective action problems, and voluntary production of local goods. ${ }^{49}$ Sometimes there is a Mayberry retrospective flavor to these accounts where individuals, powered by social capital, not only produce positive externalities for communities but also lead more psychologically fulfilling lives. ${ }^{50}$

Proposals abound for how to promote social capital through property law, with scholars variously positing roles for land use law, mixed-use zoning, social capital impact assessments of proposed land use changes or eminent domain, homeownership subsidies, foreclosure relief, and block-level residential associations. ${ }^{51}$ For example, in a detailed account of urban social capital, Sheila Foster writes about the role of land use law and shared urban commons in creating social capital. ${ }^{52}$ Anna di Robilant's recent examination of common ownership claims an important role for property rights in community gardens in fostering social capital. ${ }^{53}$ At times it appears that property determinism is at play with outsized faith in the role of property configurations, such as New Urbanist communities or homeownership zones, to produce social capital. ${ }^{54}$ Often these accounts envision that once law has fostered a sufficient stock of social capital, legal institutions will take a backseat to efficient (and social capital-enhancing) group cooperation and private ordering. ${ }^{55}$ Work such as Paula Franzese's proposals for reforming common interest communities and Bob Ellickson's scholarship contend that over-

mixing of social relations and instrumental benefits, though it is closer to the community concept in focusing on the motives underlying social relations ....").

${ }^{49}$ See Ellickson, Mixed-Income Housing, supra note 8, at 1009; Franzese, supra note 19, at 560-62; Ostrom, supra note 21, at 173, 198-99.

${ }^{50}$ See, e.g., Anna di Robilant, Common Ownership and Equality of Autonomy 60-63 (2012) (unpublished manuscript), available at http://works.bepress.com/anna_di_robilant/3 (describing social capital benefits of community gardens). See generally Putnam, supra note 2 .

${ }^{51}$ See, e.g., Alexander, supra note 19, at 852-64 (proposing social capital GIS mapping, foreclosure relief protection, eminent domain, and affordable housing to protect and promote place-based social capital); Brescia, Capital, supra note 8, at 273-74 (mortgage crisis); Fischel, supra note 17, at 113-15 (education); Foster, supra note 19, at 530-46 (2006) (urban community development); Franzese, supra note 19, at 588 (common interest communities).

${ }_{52}$ See Foster, supra note 19, at 530-42.

${ }^{53}$ See di Robilant, supra note 50, at 60 (asserting that community gardens are "crucial triggers of what scholars call a neighborhood's 'social capital'").

${ }^{54}$ See Herbert J. Gans, People and Plans: Essays on Urban Problems and Solutions 28 (1968) (critiquing physical determinism and overreliance on the capacity of urban planning to influence social outcomes).

${ }^{55}$ See supra notes $22-23$ and accompanying text. 
specified, heavy-handed, or power-centralizing laws crowd out social capital and norms. ${ }^{56}$

Scholars also seek to maintain social capital against the erosive effects of laws and policies, and to formalize the accounting of social interests alongside economic ones. Asmara Tekle Johnson and Lisa Alexander propose mandatory social capital impact assessments prior to eminent domain or land use changes likely to damage social capital (the latter suggests GIS mapping of community social capital scores). ${ }^{57}$ In a similar vein, social capital justifies recent scholarly proposals for foreclosure relief and mortgage-lending reform. ${ }^{58}$ More generally, Richard Pildes describes how law can destroy social capital by razing the physical spaces or social structures necessary for norms of cooperation and undermining reciprocity through legal interpretations dissonant with prevailing norms. ${ }^{59}$

Recently, legal scholars have leapt into the fray to propose legal institutions and policies to reduce the alleged social capital-deflating effects of racial and ethnic diversity. In his recommendation for moderate approaches to diversity engineering, Peter Schuck observes, "Managing diversity wisely while also building, or at least maintaining, social capital is among the most compelling and difficult tasks facing all societies today." ${ }^{60}$ Benjamin Barros proposes formal dispute resolution and increased privatization of common resources in order to preserve both social capital and heterogeneity in common interest communities and natu-

\footnotetext{
${ }^{56}$ See Ellickson, Order, supra note 22, at 270-72 (describing how the design of laws and legal institutions can support, or undermine, informal social control); Franzese, supra note 19 , at 561-62, 589 (stating that common interest community "planning patterns and modes of dispute resolution, with their emphasis on formalized mandates and broad enforcement mechanisms, create cultures of distrust.... [F]ormal legal institutions are called upon to accomplish what once was left (and is best left) to informal networks and social capital."); see also Lee Anne Fennell, Contracting Communities, 2004 U. Ill. L. Rev. 829, 882-85 (examining effect of servitude and contract model on the prospects for community- and normbased resolution of conflicts).

${ }_{57}^{57}$ See Alexander, supra note 19, at 854; Johnson, supra note 19, at 191.

${ }^{58}$ See Alexander, supra note 19, at 861-63; Brescia, Capital, supra note 8, at 273 (contending that community organizations and other lending reforms can infuse social capital and reduce predatory lending).

${ }^{59}$ See Pildes, supra note 16, at 2063.

${ }^{60}$ See Schuck, supra note 8 , at 84 (describing the superiority of positive incentives rather than coercive rules for managing diversity while building social capital).
} 
ral resources management. ${ }^{61}$ James Kushner endorses higher density, mixed-use New Urbanist development to increase racial integration while reducing its negative effects on social capital. ${ }^{62}$ Other scholars contend that housing integration is the long-term solution to ensuring social capital in diverse communities. ${ }^{63}$

The property scholarship posits social capital not only as an effect, but also a cause of well-functioning property institutions. Social capital enables devolution of property governance and public and private goods provision from law and government to resident groups, including homeowners associations, neighborhood and block associations, and informally governed urban "commons." ${ }^{\text {"64 }}$ Indeed, there appears to be little that social capital cannot accomplish. Property scholars contend that social capital produces interstitial governance, facilitates resident selfgovernance, reduces conflicts in common interest communities, and conserves valuable natural resources. ${ }^{65}$ Bob Ellickson is one of the leading legal writers on the importance of social capital to efficient property institutions in small-scale residential settings. His work explores how block-level associations foster and capitalize upon social capital, tightknit communities employ social capital to create and enforce norms, and rental vouchers better maintain local social capital compared to mixedincome housing. ${ }^{66}$

\footnotetext{
${ }^{61}$ See D. Benjamin Barros, Group Size, Heterogeneity, and Prosocial Behavior: Designing Legal Structures to Facilitate Cooperation in a Diverse Society, 18 Cornell J.L. \& Pub. Pol'y 203, 215-17 (2008).

${ }^{62}$ See Kushner, supra note 8, at 599-601.

${ }^{63}$ Integration advocate Florence Wagman Roisman argues that increased residential integration will mitigate the harms described by Putnam and sustain civil society over the longterm. See Roisman, supra note 8, at 519-20; see also Gerald E. Frug, The Geography of Community, 48 Stan. L. Rev. 1047, 1077 (1996).

${ }^{64}$ See Ellickson, New Institutions, supra note 19, at 83 (describing how support from social capital and "a coterminous informal social network helps an institution [such as a blocklevel association] flourish"); Franzese, supra note 19, at 588 (discussing the importance of social capital and how the regulation of common interest communities creates an environment where "social capital cannot be nurtured, let alone sustained, in settings of unbridled restrictiveness"); cf. Sheila Foster, Collective Action and the Urban Commons, 87 Notre Dame L. Rev. 57, 89-93 (2011) (arguing that high social capital may justify greater devolution to residents but often some government support is still necessary).

${ }^{65}$ See e.g., Ellickson, Mixed-Income Housing, supra note 8, at 1009; Franzese, supra note 19 , at 589-90; Kushner, supra note 8, at 600-01; Ostrom, supra note 21, at 182-84.

${ }^{66}$ See Ellickson, Mixed-Income Housing, supra note 8, at 109-10; Ellickson, New Institutions, supra note 19, at 83-84; Ellickson, Order, supra note 22, at 270-72.
} 
Perhaps the most influential and ardent proponent of social capital's role in property institutions is Elinor Ostrom, winner of the 2009 Nobel Prize. Ostrom's path-breaking studies of successful communitygoverned common pool resources showed that tragedies of the commons are not inevitable, or in game theory terms, that in prisoners' dilemmas people can make credible commitments to cooperate rather than defecting to inferior or last-best solutions. ${ }^{67}$ In several articles and a book, Ostrom heralded social capital as a "fundamental concept" for collectively managed property: groups with sufficient ex ante social capital, and with collective design rules and repeated interactions that maintain social capital stock, can successfully self-govern property. ${ }^{68}$

Turning to the policy arena, social capital is now a staple of land use planning, housing policy, and community and international development. Social capital has rocketed from printed page to policy in large part due to its capacity to support a plethora of agendas, including privatization. ${ }^{69}$ The rhetorical force of social capital (its very sociability) and its legitimation of social concerns in an era of economic policymaking drew liberals. For conservatives, social capital substitutes for government and, taken to the logical next step for some, counsels shrinking welfare - economic distress is due substantially to low social capital and best remedied with participation, not payment.

Social capital is a growing feature of land use planning - a trend unrecognized in the law scholarship and textbooks. Dozens of localities, often funded by community foundations, have completed "Social Capital Assessments" to quantitatively measure their community's social

\footnotetext{
${ }^{67}$ See Ostrom, supra note 14 , at 2-21, 26-28.

${ }^{68}$ See id.; Ostrom, supra note 21 , at 173 (noting that while there has been some "hoopla" about social capital, "[i]t is important that social capital be taken seriously and not allowed to be carried off as a fad"). She maintained that when "governments take over [communitymanaged natural resources or schools] they destroy an immense stock of social capital in short order"- an especially troubling turn of events since, in Ostrom's view, external or topdown processes are not effective at building social capital. Id. at 182.

${ }^{69}$ Ostrom's vision differs from traditional privatization models. However, the general incorporation of social capital in urban planning, land use, and property has capitalized on social capital as a justification for privatization. See Margit Mayer, The Onward Sweep of Social Capital: Causes and Consequences for Understanding Cities, Communities, and Urban Movements, 27 Int'1 J. Urb. \& Regional Res. 108, 114-16 (2003). Indeed, Blair's Fabian pamphlet cited social capital, stating, "[T]he Third Way ... will build its prosperity on human and social capital." Tony Blair, The Third Way: New Politics for the New Century 20 (London Fabian Soc'y ed., 1998).
} 
capital, at an average cost of $\$ 25,000$ to $\$ 50,000 .^{70}$ Comprehensive zoning plans describe the community "stock" of social capital and report on how to enhance social capital through zoning, support for community groups and organizations, and growth controls. ${ }^{71}$ For example, the comprehensive plan of the city of Ludington, Michigan states that, "[e]vents and community groups are an excellent indicator of a community's social capital," while the Winston-Salem Comprehensive Plan "social capital recommendations" aim to "develop opportunities to increase community interaction" and "support community organizations involved in their planning and development efforts." 72 Social capital has featured in the Environmental Impact Statement process under the National Environmental Protection Act. ${ }^{73}$ In at least two cases, residents have filed objections to highway and prison construction in their communities on the grounds of deleterious impacts to local social capital from the proposed sitings. ${ }^{74}$ Researchers Thomas Sander and Lew Feldstein, at Harvard University's social capital Saguaro Seminar, are developing formal assessments that governments can employ to evaluate the social capital impacts of proposed projects. $^{75}$

\footnotetext{
${ }^{70}$ Many of these local social capital assessments were funded by community foundations and conducted by Putnam and his team, who used the data for their research. See Doug Easterling, Promoting Community Leadership Among Community Foundations, 3 Found. Rev. 81, 83 (2011), available at http://www.cftompkins.org/wp-content/uploads/2012/07/Easter ling-Promoting-CL-among-CFs-doc-2.pdf.

${ }^{71}$ As the Forsyth County comprehensive plan declares, "Social capital is important as a planning concept because, as Putnam argues, places that are not increasing their social capital will struggle to provide their residents with the types of economic and social opportunities that make a place a truly healthy and vibrant 'community."' See North Suburban Area Plan of Forsyth County and Winston-Salem 18 (Mar. 2006), http://www.cityofws.org/ Assets/CityOfWS/Documents/Planning/Publications/AreaPlans/NSAP.pdf; see also Vision 2020 Comprehensive Plan Update City of Hamilton, Ohio 87 (Jan. 2008), http:// www.hamilton-city.org/Modules/ShowDocument.aspx?documentid=494 ("Low-density development leads to a loss of cohesive communities, sense of place, and social capital.").

${ }^{72}$ See City of Ludington, Michigan: A Comprehensive Plan 15 (May 2010), www.ludington.mi.us/docs/2009compupdatedraft050510.pdf; see also North Suburban Area Plan of Forsyth County and Winston-Salem, supra note 71, at 53.

${ }^{73}$ National Environmental Policy Act of 1969, 42 U.S.C. $§ 4332$ (2006).

${ }^{74}$ See Memorandum from New Hampshire Residents to Pamela J. Chandler, Chief, Fed. Bureau of Prisons, Social Capital Impacts of the Proposed Federal Correctional Institution in Berlin, New Hampshire (May 5, 2006), available at http://www.hks.harvard.edu/saguaro/ measurement/pdfs/berlinskimpact.pdf; Thomas Sander, Environmental Impact Statements and Their Lessons for Social Capital Analysis 4 (1999), www.hks.harvard.edu/saguaro/pdfs/ sandereisandsklessons.pdf.

${ }^{75}$ See, e.g., Lew Feldstein \& Thomas Sander, Social Capital Impact Assessment, Saguaro Seminar: Civic Engagement in America, Harvard Univ., http://www.hks.harvard.edu/var/
} 
In cities, as funds have dwindled following federal devolution to the states and shrinking state disbursements to localities, communitarianstyle ventures that claim to produce social capital have proliferated (or their publicity has increased). Community gardens, gatherings, neighborhood block grants, and other efforts to socialize city residents now ostensibly further social capital goals in an era of shrinking city funds for social services. ${ }^{76}$ Cities have subsidized social capital-enhancing New Urbanist developments with tax-increment financing, seemingly with mixed motives of promoting community sociability and responding to developer interests. ${ }^{77}$ Social capital theory also underlies recent experiments in neighborhood self-governance. As the influence of social capital and participatory empowerment burgeoned in the 1990s, Portland devolved certain land use responsibilities to neighborhood associations, and Los Angeles created neighborhood councils to hear land use and zoning requests and manage small funds for neighborhood improvement. ${ }^{78}$ The most notable of these neighborhood democracy reforms is the now-defunct Minneapolis Neighborhood Revitalization Program ("NRP"), established by the state legislature in 1990, which devolved local planning and fiscal funding to neighborhoods. ${ }^{79}$

Social capital has also permeated federal housing policy. The federal government justifies homeownership subsidies, such as the home mortgage interest deduction, in part on its alleged effect of promoting social capital in local communities. ${ }^{80}$ The Hope VI low-income housing program administered by the U.S. Department of Housing and Urban Development ("HUD") explicitly incorporates social capital. Federal guide-

ezp_site/storage/fckeditor/file/pdfs/centers-programs/programs/saguaro/pdfs/measurement/ skimpactassessment.pdf (last visted Apr. 9, 2013).

${ }^{76}$ Nonprofits, such as the Urban Affairs Association, have devoted conferences to social capital and the social reconstruction of the city and major community foundations have made social capital the centerpiece of their work. See DeFilippis, supra note 27, at 788 (describing social capital investment by community foundations).

${ }^{77}$ Greg LeRoy, TIF, Greenfields, and Sprawl: How an Incentive Created to Alleviate Slums Has Come to Subsidize Upscale Malls and New Urbanist Developments, 2 Plan. \& Envtl. L. 3, 8-10 (2008), available at http://www.goodjobsfirst.org/sites/default/files/docs/ pdf/apa.pdf.

${ }^{78}$ See Matt Leighninger, The Promise and Challenge of Neighborhood Democracy 7-8 (2008).

${ }^{79}$ See infra Section III.A.

${ }^{80}$ See Stephanie M. Stern, Reassessing the Citizen Virtues of Homeownership, 111 Colum. L. Rev. 890, 896-97, 903-05 (2011) (finding to the contrary that differences between homeowners and tenants are modest). 
lines for Hope VI public housing developments emphasize New Urbanist features claimed to enhance social interaction and build social capital, as well as to increase convenience and quality of life for residents. ${ }^{81}$ HUD, particularly under former HUD Secretary Henry Cisneros, has also advocated the social capital-related theory of "defensible space" for low-income housing. Defensible space theory claims to reduce crime by designing buildings to increase sense of community, neighbor interaction, and resident surveillance through features such as street-facing windows, single-family design, and cul-de-sacs. ${ }^{82}$ In some cases, defensible space concerns have led cities to close residential streets in order to build community social capital and reduce disorder - a stark visual of social capital's role in closing off property. ${ }^{83}$

\section{B. Social Science Evidence: The Case for Social Capital}

The prevailing narrative among legal scholars is that social capital produces economic growth and other beneficial community outcomes, promotes the productive and peaceable utilization of property, and enables self-governance structures that overcome free rider problems (the problem of free-riding on social capital is left unresolved). ${ }^{84}$ Accounts

\footnotetext{
${ }^{81}$ See Thomas H. Sander, Social Capital and New Urbanism: Leading a Civic Horse to Water?, 91 Nat'l Civic Rev. 213, 215 n.11, 216 (2002) (describing connection between social capital and New Urbanism and the increasing incorporation of New Urbanist principles into HUD low-income housing projects). See generally Principles for Inner City Neighborhood Design, A Collaboration of the Congress for New Urbanism and the U.S. Department of Housing and Urban Development, available at http://www.huduser.org/Publications/ pdf/principles.pdf (last visited Apr. 9, 2013).

${ }^{82}$ See Oscar Newman, Defensible Space: Crime Prevention Through Urban Design 1-15, 50, 61 (1972) (describing theory and design features); Blair Kamin, Building a Sense of Security, Chi. Trib., June 21, 1995, at 1, available at http://articles.chicagotribune.com/199506-21/news/9506210179_1_defensible-space-public-housing-chicago-housing-authority (describing HUD backing of defensible space theory).

${ }^{83}$ See, e.g., Oscar Newman, Defensible Space, 93 Shelterforce 8, 8 (1997), available at http://www.nhi.org/online/issues/93/defense.html (describing defensible space initiative in a Dayton, Ohio neighborhood that closed off thirty-five streets and twenty-five alleys).

${ }^{84}$ See, e.g., Raymond H. Brescia, The Cost of Inequality: Social Distance, Predatory Conduct, and the Financial Crisis, 66 N.Y.U. Ann. Surv. Am. L. 641, 679 (2011) [hereinafter Brescia, Cost] (concluding that communities with high social capital are "better off"); see also Brescia, Capital, supra note 8, at 273 ("The relative presence or strength of social capital can mean the difference between a well-functioning society and one that is riddled by corruption, crime, low levels of civic participation and high levels of mistrust of neighbors, civic institutions, and elected officials."); Ellickson, Mixed-Income Housing, supra note 8, at 1008-09 (describing social capital and the importance of "bonding social capital" at the block level); Franzese, supra note 19, at 567-69.
} 
vary, or are silent, on whether social capital changes preferences or merely mobilizes pre-existing preferences-but no matter, at the end of the day social capital does something good for communities and the nation. Before turning to my account of the dark side of residential social capital, it is worth examining these assumptions in light of social science evidence and theory.

In Bowling Alone, Putnam makes a series of bold claims about the value of social capital to communities: community-level social capital enhances local economic growth, educational outcomes, child welfare, health, and crime control. ${ }^{85}$ However, he offers only state-level data with limited controls. ${ }^{86}$ In Putnam's later research on U.S. communities, these extravagant claims are no longer present. ${ }^{87}$ Moreover, even at the state level, researchers reanalyzing Putnam's data with more rigorous controls for economic inequality, percent black population, region, and timelagged variables found that the relationship between state-level social capital scores and many outcomes lost significance altogether. ${ }^{88}$ Locally, there is little evidence that social capital improves housing outcomes or community development, with some research suggesting that higher social capital in a building or block may displace rather than reduce crime or other social ills. ${ }^{89}$ The correlation of social capital with crime reduction has been established only in urban neighborhoods, using a different construct of collective efficacy, pioneered by Robert Sampson, that fo-

\footnotetext{
${ }^{85}$ See Putnam, supra note 2 . Ben Fine notes: "Social capital offers the golden opportunity of improving the status quo without challenging it. Everything from educational outcomes through crime prevention to better psychological health can be improved if neighbours and communities would only pull together and trust and interact with one another." Ben Fine, Theories of Social Capital: Researchers Behaving Badly 4 (2010).

${ }^{86}$ See Putnam, supra note 2, at 415-24 (describing sources and methods used in book).

${ }^{87}$ This finding is also subject to a measurement effect where subjects who answer questions about community participation positively are then more likely to report satisfaction and happiness due to consistency drives and cuing.

${ }^{88}$ See Alejandro Portes \& Erik Vickstrom, Diversity, Social Capital, and Cohesion, 37 Ann. Rev. Soc. 461, 468 (2011).

${ }^{89}$ Temkin and Rohe's study of urban neighborhood social capital concluded that volunteering and organizational participation did not affect neighborhood stability. Kenneth Temkin \& William M. Rohe, Social Capital and Neighborhood Stability: An Empirical Investigation, 9 Housing Pol'y Debate 61, 84-85 (1998); see also Edward L. Glaeser \& Bruce Sacerdote, The Social Consequences of Housing, 9 J. Housing Econ. 1, 17-22 (2000); Susan Saegert et al., Social Capital and Crime in New York City's Low-Income Housing, 13 Housing Pol'y Debate 189, 219 (2002) (noting that while there was crime reduction in the housing unit, crime might have been displaced to other blocks).
} 
cuses on norms of social regulation within communities. ${ }^{90}$ There is no evidence that community social capital in the United States increases local economic growth, and the evidence of positive effects on health is inconsistent. ${ }^{91}$ Most concerning, recent research by Alejandro Portes and Erik Vickstrom calls into question the validity of Putnam's social capital measure and raises a serious question of whether social capital scores reflect an omitted variable. Portes and Vickstrom find that historical patterns of slavery and Scandinavian immigration offer a better explanation for social capital scores - a pattern they note cannot be undone by "exhorting citizens to become more participatory." 92

Research in political science, economics, and psychology suggests other stumbling blocks for social capital. First, as J. Eric Oliver observes, it is too simplistic to assume that more social or civic participation equals more democracy or other benefits because these outcomes depend on structural and political factors. ${ }^{93}$ One of those factors, as Morris Fiorina notes in his critique of social capital, is whether the civically engaged group or groups represents the interests and values of the community or of larger society. ${ }^{94} \mathrm{He}$ argues that communities may be better off with little civic engagement or robust engagement by multiple interest groups, but that the middle ground of civic engagement often represents capture by insular minority interests. ${ }^{95}$ In addition, gains to certain aspects of social capital often come at the expense of other aspects of social capital or other values. In Democracy in Suburbia, Oliver argues that suburbanization has partially demobilized citizens from local politics. ${ }^{96}$ Class and background homogeneity in the suburbs lessens political and social conflict and reduces the need for political engagement, a

\footnotetext{
${ }^{90}$ See Jeffrey D. Morenoff, Robert J. Sampson \& Stephen W. Raudenbush, Neighborhood Inequality, Collective Efficacy, and the Spatial Dynamics of Urban Violence, 39 Criminology 517,518 (2001).

${ }^{91}$ See DeFilippis, supra note 27, at 798 (criticizing social capital for failing to create economic development); Megan Perry et al., Social Capital and Health Care Experiences Among Low-Income Individuals, 98 Am. J. Pub. Health 330, 330-35 (2008) (reporting mixed findings).

${ }_{92}$ Portes \& Vickstrom, supra note 88 , at 468-69.

${ }^{93}$ See J. Eric Oliver, Democracy in Suburbia 190 (2001).

${ }^{94}$ See Morris P. Fiorina, Extreme Voices: A Dark Side of Civic Engagement, in Civic Engagement in American Democracy 395, 403 (Theda Skocpol \& Morris P. Fiorina eds., 1999).

${ }^{95}$ See id. at 418.

${ }^{96}$ See Oliver, supra note 93, at 188.
} 
harm which in his view outweighs the benefits of small community size to social capital. ${ }^{97}$

Second, economic theory suggests some limitations to social capital. Free-riding and displacement limit the amount of welfare enhancement from social capital, while the availability of substitutes for social capital undermines its claimed primacy to modern life. In their economic critique of social capital, Steven Durlauf and Marcel Fafchamps describe these impediments. ${ }^{98}$ Displacement occurs when social capital redistributes a fixed supply of goods rather than creates wealth. ${ }^{99}$ For example, if a local budget is limited and fixed, neighborhood social capital that enables a neighborhood to organize to demand better trash pick-up services may result in reductions in the quality and promptness of trash pick-up in other neighborhoods. In some cases, redistribution can be desirable for equitable or historical reasons, but in other cases, it may be socially undesirable or reflect rent-seeking. Free-riding on social capital can also limit the incentives for its production and its net efficacy to society. ${ }^{100}$ Sheila Foster describes this problem in her discussion of free-riding as an impediment to resident collective action in the urban commons. ${ }^{101}$ Perhaps most importantly, the availability of substitutes calls into question the necessity of abundant social capital. Communities with lower social capital can adopt alternatives such as taxation, private provision of goods (for example, hiring private security or other services), local government institutions, laws, and non-profit organizations to achieve the outcomes ascribed to social capital. ${ }^{102}$

Last, drawing on psychology research, I contend that in some instances social capital may create second-order effects where the process of collective action, which may be socially positive in the first instance, subsequently creates negative norms and behaviors. Indeed, some of what we perceive as collective action "failure" may occur, and legal and market substitutes may arise, because of the risk of negative spillovers from the social capital and in-group formation necessary to support informal collective action. The local social capital described by Putnam

\footnotetext{
${ }^{97}$ See id.

${ }^{98}$ See Steven N. Durlauf \& Marcel Fafchamps, Social Capital 16 (Nat'1 Bureau of Econ. Research, Working Paper No. 10485, 2004), available at http://www.nber.org/ papers/w10485.pdf.

${ }^{99}$ See id. at 15.

${ }^{100}$ See id. at 24.

${ }^{101}$ See Foster, supra note 64, at 71-72.

${ }^{102}$ See Durlauf \& Fafchamps, supra note 98, at 11, 13.
} 
tracks the social psychological concept of self-preferencing in-groups. In-groups are an inevitable facet of social life, but strengthening ingroups, empowering them with decision-making authority over interests beyond the group, and failing to supply laws or norms to constrain their actions can have substantial negative effects. In-groups typically preference the interests of their group and adopt beliefs that support their group and further its social position. ${ }^{103}$ In doing so, members of ingroups, particularly tight-knit or high-status groups, frequently develop negative views of or behaviors toward members of other groups. ${ }^{104}$ Work by Irving Janis on "group think" shows how intense in-group pressures contract independent moral judgment and dissenting action. ${ }^{105}$ There is also a large body of evidence, considered by Cass Sunstein in the legal scholarship, on how deliberating (here collectively cooperating) groups go to extremes. ${ }^{106}$ The psychological tendency to reduce dissonance between beliefs and actions by changing beliefs to support behavior provides another explanation for intensification of belief through the process of collective action. ${ }^{107}$ The fact that people have multiple ingroup affiliations may mitigate these harms but does not eliminate them, particularly when a person identifies strongly with one or a small number of in-groups. ${ }^{108}$

In conclusion, the strong form of social capital-Putnam's expansive social capital measure and exuberant outcomes claims-has limited utility. It is under-specified, near limitless, the outcomes evidence is weak, and recent reanalysis suggests that social capital scores reflect omitted variables and historical determinants. ${ }^{109}$ To the extent that legal commentators mean to adopt Putnam's capacious social capital construct as scientifically established and credit its array of claimed outcomes, their case is weak for the reasons described above. However, much of the legal literature contemplates a more modest iteration of social capital, upon which this Article focuses: the concerted effect of social net-

\footnotetext{
${ }^{103}$ See Miles Hewstone et al., Intergroup Bias, 53 Ann. Rev. Psychol. 575, 576 (2002) (reviewing literature on in-group bias).

${ }^{104}$ See id. at 585.

${ }^{105}$ See Janis, supra note 33, at 10-13, 197-98.

${ }^{106}$ See Sunstein, supra note 33, at 5-7, 14-16, 36-37, 41-42.

${ }^{107}$ See Festinger, supra note 33, at 12-24, 261-62.

${ }^{108}$ See Hewstone et al., supra note 103, at 591-93.

${ }^{109}$ See Portes \& Vickstrom, supra note 88, at 470-77; Joel Sobel, Can We Trust Social Capital?, 40 J. Econ. Literature 139, 140 (2002) (writing that Putnam "comes close to equating social capital with good outcomes"). See generally Section I.B.
} 
works, in-group trust, and tastes for participation on collective action within moderately connected or tight-knit groups. ${ }^{110}$ While not eliminating capaciousness and tautology, this construct does at least capture an intuitive aspect of social life and one that is supported in several respects by social psychology research. ${ }^{111}$ We need not dismiss this iteration of social capital, but we should be skeptical of its ability to sustain property institutions and wary of its potential harms.

\section{The DARK SidE OF RESIDENTIAL SocIAL CAPITAL}

The enthusiasm for social capital in property law has obscured social capital's capacity to effectuate illiberal exclusion and create and advance factions contrary to the public interest. Notably, social capital is at the heart of Madison's factions, citizen groups that advance interests contrary to the public good, described in Federalist 10, as well as factions' economic cousins, cartels. ${ }^{112}$ Madison defined factions as "a number of citizens, whether amounting to a majority or minority of the whole, who are united and actuated by some common impulse of passion, or of interest, adverse to the rights of other citizens, or to the permanent and aggregate interests of the community." ${ }^{113}$ In a similar vein, Adam Smith observed in The Wealth of Nations that networks and trust can create monopolization and a group whose "interest is ... directly opposite to that of the great body of the people."114 Madison perceived factions in the political sense of dominant interest group capture of the political process and thus was less concerned with minority factions (wrongly, as

\footnotetext{
${ }^{110}$ See, e.g., supra notes 64-66 and accompanying text.

${ }^{111}$ See, e.g., Janis, supra note 33, at 199-201. Notably, informal and quasi-formal forms of social interaction and participation, often occurring in small groups and private interactions, may have powerful effects not studied or successfully captured by the quantitative research described in this Section.

${ }^{112}$ See The Federalist No. 10, at 56 (James Madison) (Bantam Dell 2003). But see Peter H. Schuck, The Limits of Law: Essays on Democratic Governance 218-22 (2000) (contending that factions are essential to a vibrant polity and that the power of diffuse interests, different forms of political resources, and the political system's increasing resistance to factional domination reduce the magnitude of danger from factions).

${ }^{113}$ See The Federalist No. 10, supra note 112, at 51. This definition focuses on negative outcomes, as well as negative intentions, and therefore parallels the tendencies toward tautology in the social capital construct.

${ }^{114}$ Adam Smith, An Inquiry into the Nature and Causes of the Wealth of Nations 307 (Oxford Univ. Press 1993) (1776).
} 
scholars of interest group politics have pointed out). ${ }^{115}$ As the residential context illustrates, factions operate through informal action and coordination as well as political lobbying, and both minority and majority factions can cause harm.

In considering solutions to the problem of factions, Madison observed that "[1]iberty is to faction, what air is to fire." Putnam and the social capitalists may have the better of Madison. It is not liberty but networks and participation that incite and explode the power of factions, which are, at least at the outset, informal groups with all of the collective action barriers that face self-organizing groups. Recall the constituent elements of social capital: cohesive groups and networks, reciprocity, tastes for participation, civic engagement, and trust. Social ties spread information necessary for planning concerted action, reinforce dominant norms, and, coupled with reciprocity, recruit participants who might otherwise object. Madison himself described what we now refer to as diffusion in local social networks: the problem of passions spreading to create a majority faction. ${ }^{117}$ Trust, a central element of social capital, may be particularly important when the action contemplated is collusive, illegal, or otherwise socially objectionable. ${ }^{118}$ Group members must trust others in the relevant community not to defect or report them to authorities. Tastes for participation predict greater inclination and competence at organizing collective action. And social cohesion and group identity provide powerful in-kind benefits that counteract the costs of collective action. ${ }^{119}$

In residential communities, collective activity by resident factions and cartels to constrain housing supply or entrance is facilitated by the same cohesive networks, tastes for participation, experience with organiza-

\footnotetext{
${ }^{115}$ See Bruce A. Ackerman, Beyond Carolene Products, 98 Harv. L. Rev. 713, 726-27, 742,745 (1985).

${ }^{116}$ The Federalist No. 10, supra note 112, at 51.

${ }^{117} \mathrm{Cf}$. id. at 57-58 (stating that a large republic will prevent factions' passions from spreading to become a majority). Madison also argued that it is easier for small numbers of individuals to work together. Id. at 54-55, 57.

${ }^{118}$ As Margaret Levi observes, "[Neighborhoods] promote trust of those you know and distrust of those you do not, those not in the neighborhood or outside the networks." Margaret Levi, Social and Unsocial Capital: A Review Essay of Robert Putnam's Making Democracy Work, 24 Pol. \& Soc'y 45, 51 (1996).

${ }^{119}$ See Roger Waldinger, The 'Other Side' of Embeddedness: A Case-Study of the Interplay of Economy and Ethnicity, 18 Ethnic \& Racial Stud. 555, 557 (1995).
} 
tions, and in-group trust attributed to positive social capital. ${ }^{120}$ Indeed, bonding social capital, with its elements of group cohesion and insularity, reciprocity, and collective engagement, is perhaps uniquely wellsuited to producing exclusion-likely more so than democracy or other claimed benefits. This may explain why social capital features so prominently in Ostrom's research on open-access natural resource commons where preserving the resource often necessitates exclusion of entrants or uses. ${ }^{121}$ In the residential context, there is a robust correlation between high social capital and racial exclusion, though the studies to date do not establish causation. ${ }^{122}$ Qualitative studies of bonding capital, often in the context of ethnic control of industries, also provide some empirical support for the tendency of cohesive social capital to confer gains to ingroups at the expense of closing markets. ${ }^{123}$ In general, the evidence for social capital's role in factions and exclusion is difficult to assess quantitatively through standard outcomes measures: If high social capital produces collusive behavior, it may improve some local and state indicators, but impose harms on society and the national economy that are difficult to link causally.

In addition to its capacity to effectuate factions, social capital may also create or intensify factions by bonding together groups that then adopt group-preferencing beliefs and agendas. The type of collective action envisioned by social capitalists - intensive, reiterative, and in pursuit of a common goal-may intensify preferences by escalating group identity and in-group dynamics and increasing the cost of dissent. As previously discussed, a large body of evidence in social psychology supports these effects: Research illustrates the vulnerability of groups to "group think," the effect of dense social networks on conformity, and the tendency toward cognitive dissonance where people change beliefs to make them consonant with their actions. ${ }^{124}$ Moreover, some research suggests that group bias tracks social position and may create a greater propensity for these effects among high-status groups. ${ }^{125}$

\footnotetext{
${ }^{120}$ Group collusion to restrain supply is problematic when the property in question has demand beyond the group and its restraint is socially harmful, or when the internal distribution of property is inegalitarian.

${ }^{121}$ See, e.g., Ostrom, supra note 21 , at 173-79, 182-84.

${ }^{122}$ See supra text accompanying notes 9-10.

${ }^{123}$ See Portes, supra note 25, at 15.

${ }^{124}$ See Festinger, supra note 33, at 12-24; Janis, supra note 33, at 10-13, 197.

${ }^{125}$ High-status groups, or factions, tend to show more bias apart from any effect of wealth or resources, and there is some evidence to suggest that this effect is more pronounced when
} 
Endeavoring to raise social capital in a town, neighborhood, or block is more likely to coalesce or strengthen factional subgroups than to further the interests of the broader residential or social collective. The cost of creating and maintaining social capital is lower in small and homogenous groups, all else constant. As a result, social capital disproportionately advances factions, which tend to be discrete and homogenous groups, compared to large groups and more diverse communities of interest. The strong interests entailed in factions also dovetail with social capital. Because social capital accumulation requires significant investment and effort by group members, it is most likely to effectuate collective action where participants have strong motivations and will capture a high proportion of the benefits, as is often the case with bad acts as well as private goods. In addition, in developed economies, social networks and informal institutions may be most effective at providing goods that cannot be supplied at a low-cost or at all from the market or government. It is possible that social capital's dark side is so substantial in part because legal and market substitutes are comparatively less available for bad acts, illiberalism, and illegal activity (though not unavailable as evidenced by laws such as exclusionary zoning and racially restrictive covenants).

Madison was convinced one could not control the causes of factions. In theory, however, reducing the social capital in an area or group can address the mediator of public bads from factions (social capital partially mediates the relationship between "passions" and faction effects). Perhaps Madison's views of the protective power of diverse interests and the increased costs of organizing factions in large republics track the idea of breaking up social capital. However, Madison neglected substitutes for social capital. Factions in small geographic areas, such as neighborhoods or small towns, which have the advantage of close proximity and social ties, may employ social capital, whereas factions at a larger scale often rely more heavily on the substitutes of economic and political capital. This lends support to Carol Rose's vigorous refutation of Madison's arguments about the particular susceptibility of local governments to faction. ${ }^{126}$ It also suggests a partial explanation for Madi-

the groups perceive their status differential narrowing or a threat to group status. See Hewstone et al., supra note 103, at 585 .

${ }^{126}$ See, e.g., Carol M. Rose, Takings, Federalism, Norms, 105 Yale L.J. 1121, 1132-34 (1996) (reviewing William A. Fischel, Regulatory Takings: Law, Economics, and Politics (1995)). 
son's concern about factions in small geographic areas, as well as the tenacious modern-day suspicion of local government corruption. Perhaps, as intrinsically social beings, social capital-fueled actions at the local level are not more potent but rather more salient, evocative, and squarely within our experience, than political lobbying, trade associations, and other substitutes that make factions effective at larger scales. Indeed, it may be that Madison suffered from availability bias.

Concededly, the relationship between social capital and factions is imprecise, and the dark side of social capital is no more delimited than its positive aspect. Social capital does not create a particular interest, in the way we typically conceive of factions. I employ factions as a conceptual umbrella, rather than a perfect analog, for the negative externalities of social capital. The dark side of social capital and its role in factions also suffers unavoidably from the same capaciousness and tendency toward tautology that plagues the social capital construct. ${ }^{127}$ I do not resist these critiques or their implications. My contention is that, taking the social capital construct as I find it, local social capital elicits both socially positive collective action and factional collective action desirable and sometimes efficient within the group, but harmful to the broader community. If social capital ultimately proves too encompassing to usefully describe positive or negative local effects, then it should be abandoned in property discourse.

Property scholars have been neglectful of, but not blind to, the dark side of social capital. ${ }^{128}$ The property scholarship notes in passing negative uses of social capital, but does not address the magnitude or implications of social capital's dark side. ${ }^{129}$ Scholars have, however, raised related concerns about illiberalism in commons situations. Hanoch Dagan and Michael Heller focus on constraints on exit and voice as threats

\footnotetext{
${ }^{127}$ Of course, there are some limits to my account and the social capital construct, such as situations where distrust or a lack of civic orientation within the group fuels its collective action.

${ }^{128}$ Outside of property law, Frank Cross endorses the value of the trust component of social capital to transactional law, but recognizes the dark side of trust and notes the problems of ethnic control of trade and discrimination from strong affective trust. See Frank B. Cross, Law and Trust, 93 Geo. L.J. 1457, 1532-43 (2005).

${ }^{129}$ See Franzese, supra note 19, at 568; cf. Foster, supra note 19, at 563 (exploring social capital's benefits for urban communities but observing that "the goal of providing 'bridging' capital may be undermined by social prejudices and the exclusionary effects of social networks in racially and economically homogenous neighborhoods").
} 
to a liberal commons. ${ }^{130}$ Carol Rose argues for at least a minimal framework of law to address concerns of hierarchical, non-egalitarian, and sexist practices in Ostrom's commons. ${ }^{131}$ Other perspectives embrace markets and implicitly minimize the role of self-governance, such as work by Thomas Merrill and Henry Smith on information costs and standardized property forms. ${ }^{132}$

In the social science literature, amid droves of papers lauding social capital, a smaller number have explored social capital's dark side. ${ }^{133}$ In her work on community-managed natural resources, Ostrom acknowledges and describes the dark side of social capital but does not grapple with whether or when this dark side should limit her proposals for selfgovernance of natural resource commons. ${ }^{134}$ Putnam readily concedes that bonding capital can be exclusive, but claims two intrinsic safeguards. First, he contends that associational participation and civic engagement promote tolerance, and notes that social capital scores positively correlate with tolerance. ${ }^{135}$ In addition to the reliability issues with self-report, the fact that individuals living in segregated communities and likely participating in homogenous groups and organizations report more tolerance may prove little. At the state level, if, as Portes and Vickstrom maintain, low state social capital scores reflect historic patterns of slavery, it is not surprising that more tolerant states report higher social capital. ${ }^{136}$ Second, Putnam maintains that bridging ties constrain

\footnotetext{
${ }^{130}$ Hanoch Dagan \& Michael A. Heller, The Liberal Commons, 110 Yale L.J. 549, 56768, 590-91 (2001).

${ }^{131}$ See Rose, supra note 29, at 33, 44.

${ }^{132}$ See Thomas W. Merrill \& Henry E. Smith, Optimal Standardization in the Law of Property: The Numerus Clausus Principle, 110 Yale L.J. 1, 8-9 (2000).

${ }^{133}$ See Jan W. van Deth \& Sonja Zmerli, Introduction: Civicness, Equality, and Democracy-A "Dark Side" of Social Capital?, 53 Am. Behav. Scientist 631, 632-38 (2010) (reviewing social science literature on dark sides of social capital and introducing contributions to a recent symposium on social capital's detrimental political effects); see also Fine, supra note 85 , at 5 (noting that among social scientists the critics of social capital are "heavily outweighed"). The social science accounts of social capital's dark side often focus on extreme examples of mafia activity, gangs, genocidal atrocities, and insular, religious solidarity. See Levi, supra note 118, at 52 (describing how the mafia uses bridging ties within vertical relationships for organized crime); Portes, supra note 25, at 18 (describing how negative social capital, or embeddedness in social structures, fuels "[m]afia families, prostitution and gambling rings, and youth gangs"); Putnam, supra note 2, at 21-22 (describing how negative social capital enabled the Timothy McVeigh bombing, urban gangs, and the Ku Klux Klan).

${ }^{134}$ See, e.g., Ostrom, supra note 21 , at 176-77.

135 Putnam, supra note 2, at 355-56.

${ }^{136}$ See Portes \& Vickstrom, supra note 88, at 467-69.
} 
illiberal effects by connecting geographically and socially distant individuals, facilitating diffusion of information and ideas, and generating broader identities. ${ }^{137}$ Yet, we have had difficulty engineering the types of bridging ties that trump bonding capital, promote inclusion and tolerance, connect disadvantaged people to opportunities, and create rather than redistribute wealth. ${ }^{138}$ Bridging capital often has a limited radius, necessitating a plethora of bridging ties to ensure broader solidarity (for example, labor unions bridged across race but not income). And once achieved, bridging ties and capital may morph into bonding capital. While bridging capital has some value to residential property, it is doubtful that it can fully remedy the negative externalities of local bonding capital.

My account challenges the legal scholarship's depiction of social capital as a positive good, and augments the social science literature with a view of the pervasive, sometimes quotidian nature of social capital's dark side in residential property. The enthusiasm for promoting residential social capital has not confronted the disquieting reality of seemingly abundant negative social capital in localities - and the potential for social capital engineering, if effective, to exacerbate such harms. ${ }^{139}$ Social capital often functions as a norm-neutral infrastructure that effectuates motivations, which include prejudice, risk-aversion, and rent-seeking. When the social capital that legal scholars and policymakers are attempting to build is mere cohesion, without a strong normative valence toward public interest values, liberalism, altruism, or positive social regulation, there is little reason to assume that such ventures will be welfareenhancing or egalitarian. This is not to claim that legal proposals or initiatives to promote social capital are solely responsible for these ills, which derive from powerful norms and financial incentives. Rather, it is to elucidate, in the context of anemic residential norms regarding extralocal obligations to the public good, the problem with proposals to promote social capital while diminishing the role of law.

${ }^{137}$ See Putnam, supra note 2, at 23; Wilfred Dolfsma \& Charlie Dannreuther, Subjects and Boundaries: Contesting Social Capital-Based Policies, 37 J. Econ. Issues 405, 407-10 (2003).

${ }^{138}$ See, e.g., Madeleine Leonard, Bonding and Bridging Social Capital: Reflections from Belfast, 38 Soc. 927, 941 (2004).

${ }^{139}$ But see Lee Anne Fennell, Homeownership 2.0, 102 Nw. U. L. Rev. 1047, 1098-100 (2008) (referring to reducing investment stake risk through proposed homeownership form, which splits consumption and use interests between different owners, might lessen both beneficial forms of "collective control" and negative forms such as exclusion). 
Interestingly, my analysis of sundown towns and exclusionary suburbs also suggests that bonding social capital can operate effectively and negatively, if at a higher cost, beyond the scale of small groups. Bob Ellickson has argued that bonding social capital functions effectively only in small-scale settings, such as a block or median size homeowners association. ${ }^{140}$ In his view, lawmakers should be more concerned about policing at the larger scales of neighborhoods and localities, where social capital formation is limited. ${ }^{141}$ The case studies in this Article suggest that while scale matters, strong interests and bridging ties can overcome the higher transaction costs of social capital development and deployment at the scales of neighborhoods and towns. A critical mass of highly motivated actors appears quite capable of recruiting like-minded others through bridging ties, developing cohesive groups and intra-group norms, and engaging in coordinated behavior that disadvantages outsiders or out-groups.

In the balance of this Part, I consider the alleged deficit of social capital and proposals to increase residential social capital through the lenses of residential segregation and land cartels. My examples are retrospective accounts intended to illustrate social capital's role in residential factions and exclusion, not prospective hypothesis-testing or conclusive empirical proof. My examination of the dark side of social capital in residential property raises questions of whether law should attempt to affirmatively weaken residential social bonds, perhaps with measures such as incentives for mobility or heavy subsidies for economic integration. I mainly save these questions for future work. In Part V, however, I do suggest that property institutions with greater reliance on markets and laws, among other alternatives, may foster more inclusive forms of solidarity than property gemeinschafts and informal collectives.

\section{A. Sundown Towns: Social Capital, Racial Segregation, and Bad Norm Lock-In}

In the early to mid-twentieth century, "sundown towns" across the United States evicted black residents and visitors through threats, labor

\footnotetext{
${ }^{140}$ See Robert C. Ellickson, The Puzzle of the Optimal Social Composition of Neighborhoods, in The Tiebout Model at Fifty: Essays in Public Economics in Honor of Wallace Oates 199, 204-06 (William A. Fischel ed., 2006) [hereinafter Ellickson, Social Composition].

${ }^{141}$ I thank Bob Ellickson for his discussion with me of his views on this point.
} 
market exclusion, violence, and signs advising blacks, "Don't Let the Sun Go Down on You in [town name]."142 These towns illustrate a larger national phenomenon - in an era Putnam claims as rich in social capital, white residents worked together zealously to maintain racial homogeneity. Contemporary racial segregation and urban poverty are rooted in part in this national history of racial purging, which appears to have been effectuated through considerable social capital. ${ }^{143}$

In sundown towns, collective action was embedded in dense networks of social ties that spread information about riots, pledges, mob violence, and other coordinated action and channeled anti-black norms. Community cohesion helped to reward participants with social standing and group identity - benefits in addition to any implicit compensation they derived from racist acts. Groups of residents or business owners gathered to sign pledges not to employ blacks or to allow them to live in the area. ${ }^{144}$ Residents converged on blacks to warn them to leave town. ${ }^{145}$ Civic engagement and political participation produced sundown ordinances and laws requiring resident approval before subsidized housing could be built. ${ }^{146}$ Social network linkages to local realtors, bankers, grocery store and gas station owners, and town officials meant that blacks

\footnotetext{
${ }^{142}$ See James W. Loewen, Sundown Towns: A Hidden Dimension of American Racism 34, 36-37, 99-101 (2005). Loewen estimates that at least 3000 and as many as 15,000 independent towns "went sundown" between 1890 and 1930, and several thousand sundown suburbs formed between 1900 and 1968. See id. at 79-80. Historians have critiqued Loewen's research for its lack of attention to black agency, its erratic substantiation, and its claims about the northern migration. See Luther James Adams, Sundown Towns: A Hidden Dimension of American Racism, 93 J. Am. Hist. 601, 602 (2006) (book review) (praising Loewen's massive and well-documented study but critiquing the limited attention to the black experience); Kenneth Joel Zogry, Sundown Towns: A Hidden Dimension of American Racism by James W. Loewen, 29 Pub. Historian 105, 106-07 (2007) (critiquing inadequate fact documentation and lack of attention to black reactions and agency). But no historian has disputed the fact of sundown towns. Zogry, supra, at 105 ("There is no question that the premise of Sundown Towns is correct.").

${ }^{143}$ Intrinsic satisfaction with racist acts no doubt also helped overcome collective actions and convince perpetrators to pay the costs of action and face the threat, concededly not large in most areas, of arrest or prosecution. See Thomas J. Sugrue, The Origins of the Urban Crisis: Race and Inequality in Postwar Detroit 209-50 (1996). Some towns still flaunted sundown signs as of 1990, and today some small Southern towns display signs of black mules at their town lines. See Loewen, supra note 142, at 380.

${ }^{144}$ See Loewen, supra note 142, at 249; see also Ray Stannard Baker, Following the Color Line: An Account of Negro Citizenship in the American Democracy 120, 130 (1908).

${ }^{145}$ As the Illinois State Register recorded in 1908, "A Negro is an unwelcome visitor and is soon informed he must not remain in the town." Loewen, supra note 142, at 227.

${ }^{146}$ See id. at 253.
} 
could be excluded not only from jobs, but also from necessities of daily living. ${ }^{147}$ Intergenerational closure, a key aspect in some iterations of social capital, was employed by white parents to harass black children either directly or through their children. ${ }^{148}$ And bridging ties reduced the costs of exclusion by carrying news about town reputations that deterred black entry and spread information about the trend of local racial purging - many towns "went sundown" after residents learned about nearby sundown towns.

Participation in community organizations, a central constituent of social capital, also facilitated racial exclusion-historically, an important purpose of neighborhood clubs and associations was racial exclusion. ${ }^{149}$ Thomas Sugrue's history of Detroit describes how neighborhood associations that "saw their purpose as upholding the values of selfgovernment and participatory democracy" organized to keep blacks from moving into their neighborhoods in order to protect property values and the "character" of their communities. ${ }^{150}$ For example, in one Detroit West Side neighborhood, over six hundred residents held an emergency meeting to form a neighborhood association in response to a black family moving into the area. ${ }^{151}$ The National Association of Community Associations organized "to keep the colored race from encroaching on the rights of the property owners by buying into the neighborhood." 152 "Citizen committees" coordinated to drive out blacks and "Farmers' Commercial Clubs" sought to replace black residents with white farmers. ${ }^{153}$ Following Shelley v. Kraemer, neighborhood and civic associations across the country organized to flout the decision through tactics ranging from harassment to abuse of nonconforming use ordinances. ${ }^{154}$

In addition to effectuating racial purging, solidaristic social capital likely intensified racist preferences and locked in bad norms. Recall that

\footnotetext{
${ }^{147}$ See id. at 234, 259-62.

${ }^{148}$ See id. at 265-66.

${ }^{149}$ For example, one of the earliest razings of a Chinese neighborhood occurred in 1885 when 150 miners and railroad workers, led by the Knights of Labor, attacked hundreds of Chinese-American miners, drove them out of town, and then burned their homes. See id. at $50-51$.

${ }^{150}$ See Sugrue, supra note 143, at 211.

${ }^{151}$ Id. at 214.

${ }^{152}$ Id. at 219.

${ }^{153}$ Loewen, supra note 142 , at $84,241-42$.

${ }^{154}$ For example, the Federated Property Owners homeowners association "called for a citywide network" to monitor, harass, and manipulate prices. See Sugrue, supra note 143, at 221.
} 
groups tightly bound together with social capital are likely to develop attitudes and pursue actions that preference their own group. ${ }^{155}$ For these reasons, anti-social action may spiral over time-indeed, sundown towns may be a vigilante version of how deliberating groups go to extremes. ${ }^{156}$ On the omission side of preference construction and escalation, cohesive social capital tends to lock in bad norms and preferences that hinder or foreclose change. Dense ties mean that dissent would cause friction between close-knit community members and threaten social estrangement. ${ }^{157}$ Social ties and the rapid spread of information through local networks also enable groups to punish "defectors," in the case of sundown towns by retaliating against whites who hired, housed, or befriended blacks. ${ }^{158}$

Interestingly, the most recent influence of social capital on residential racial segregation is normative. Putnam's highly publicized 2007 social capital research claims (contrary to the weight of the evidence on this question) that residential racial diversity dramatically lowers social capital. ${ }^{159}$ These claims have seeped into public discourse and beliefs. Social capital theory also maintains, with limited evidence, that community flourishing and economic success rely on residential behaviors that Americans believe are intrinsically uncharacteristic of blacks and unlikely to occur in racially integrated or otherwise heterogeneous communities. Residential racial beliefs link blacks and integrated neighborhoods

\footnotetext{
${ }^{155}$ See supra notes $103-08$ and accompanying text.

${ }^{156}$ See Janis, supra note 33, at 12-13; see also Sunstein, supra note 33, at 3-7.

${ }^{157}$ Interviews and oral histories suggest that some residents disagreed with such actions (or at least claimed to in hindsight) but did not speak up from fear of retaliation. See Loewen, supra note 142, at 232 .

${ }^{158}$ See id. at $244,271$.

${ }^{159}$ See Putnam, supra note 1. A line of subsequent studies using more robust controls and sophisticated analytical techniques finds that the effect of neighborhood diversity on social capital claimed by Putnam is small and contingent on contextual factors like inequality and segregation. See Edward Fieldhouse \& David Cutts, Does Diversity Damage Social Capital? A Comparative Study of Neighbourhood Diversity and Social Capital in the US and Britain, 43 Canadian J. Pol. Sci. 289, 307 (2010) ("[A] very large proportion of [the effect of diversity on neighborhood norms] is attributable to [individual and neighborhood] characteristics ....”); Natalia Letki, Does Diversity Erode Social Cohesion? Social Capital and Race in British Neighbourhoods, 56 Pol. Stud. 99, 118-19 (2008); Melissa J. Marschall \& Dietlind Stolle, Race and the City: Neighborhood Context and the Development of Generalized Trust, 26 Pol. Behav. 125, 142 (2004) (finding large effect of neighborhood educational attainment); see also David E. Campbell, Why We Vote: How Schools and Communities Shape Our Civic Life 64 (2006) (finding that in communities that are looser-knit and more politically heterogeneous, there is less informal civic engagement but more political activity and voting).
} 
to the antitheses of residential social capital: low neighboring, weak community contribution, and disorderly behavior. ${ }^{160}$ By locating prosperity in solidarity and cooperation, social capital appears to validate the reasons whites cite for opposing black entry: concern over community decline and falling property values. ${ }^{161}$ It seems that the sundown signs have been replaced by allegedly more benign and "scientific" concerns about cooperation and collective action-delicate processes that can be undone by heterogeneity as well as by prejudice itself.

\section{B. Exclusionary Zoning: Social Capital and Local Land Cartels}

The efforts of suburban land cartels to restrain housing supply through monopoly zoning and exclusionary land use regulations are a topic of great interest and consternation to property law scholars. ${ }^{162}$ These regulations include large minimum lot-sizes, zoning exclusively for single-family housing, growth controls, and discriminatory enforcement of housing codes against rentals. There has been vigorous debate about the "monopoly zoning hypothesis" and its effect on housing consumers. ${ }^{163}$ The weight of the evidence to date indicates that in localities with strong monopoly power and politically powerful homeowners, exclusionary zoning reduces the rate and density of housing development below the optimal value of the land in a competitive market. ${ }^{164}$ This arti-

\footnotetext{
${ }^{160}$ See Lawrence Bobo \& Camille L. Zubrinsky, Attitudes on Residential Integration: Perceived Status Differences, Mere In-Group Preference, or Racial Prejudice?, 74 Soc. Forces 883, 896 (1996); Reynolds Farley et al., Stereotypes and Segregation: Neighborhoods in the Detroit Area, 100 Am. J. Soc. 750,769 (1994) (finding that most whites rate blacks as more likely to live off of welfare and less easy to get along with); Robert J. Sampson \& Stephen W. Raudenbush, Seeing Disorder: Neighborhood Stigma and the Social Construction of "Broken Windows," 67 Soc. Psychol. Q. 319, 336-37 (2004).

${ }^{161}$ See Alberto Alesina \& Eliana La Ferrara, Participation in Heterogeneous Communities, 115 Q.J. Econ. 847, 850, 886 (2000).

162 See Anthony Downs, New Visions for Metropolitan America 20 (1994). See generally Robert C. Ellickson, Suburban Growth Controls: An Economic and Legal Analysis, 86 Yale L.J. 385 (1977) [hereinafter Ellickson, Suburban Growth Controls].

${ }^{163}$ It has proven challenging to parse empirically whether price increases are due to the impact of land use regulation on improving housing and providing desirable amenities or constricting supply (for example, monopoly). See John M. Quigley \& Larry A. Rosenthal, The Effects of Land Use Regulation on the Price of Housing: What Do We Know? What Can We Learn?, 8 Cityscape 69, 70, 81 (2005) (describing methodological challenges).

${ }^{164}$ See, e.g., William A. Fischel, Political Structure and Exclusionary Zoning: Are Small Suburbs the Big Problem?, in Fiscal Decentralization and Land Policies 130 (Gregory K. Ingram and Yu-Hung Hong eds., 2008), available at https://www.lincolninst.edu/pubs/dl/ 2105_1427_LP2007-ch05-Political-Structure-and-Exclusionary-Zoning-Are-Small-Suburbs-
} 
ficially constricts supply and increases housing prices and segregation. Recent evidence from the Pew Foundation shows that economic residential segregation has increased dramatically across the past three decades; racial segregation is declining but substantial. ${ }^{165}$ We need not specify a point of optimal economic, or racial, integration in order to conclude that our extraordinarily high level of segregation is concerning. ${ }^{166}$

In localities across the United States, social capital helps to effectuate land cartels through both informal and formal (legal) coordination to maintain exclusionary zoning. High social capital entails dense networks, in-group trust, and tastes for participation that facilitate coordination and bring to light opportunities to engage in monopoly behavior. The diamond merchants of New York and other tight-knit groups, lauded for their self-regulation without law, are also examples of how social capital promotes oligopoly to the detriment of market efficiency. ${ }^{167}$ In their economic critique of social capital, Durlauf and Fafchamps offer as an example collusion to drive up prices between fishing groups from different fishing grounds, selling on the same market, who are connected by strong bridging ties and high social capital. ${ }^{168}$ Applied to local resi-

the-Big-Problem.pdf [hereinafter Fischel, Small Suburbs] (concluding that monopoly zoning occurs in fragmented metropolitan statistical areas populated with small suburbs). Research by James Thorson found that communities with more monopoly power have higher house prices but are not more restrictive in producing new housing. Thorson suggested that in addition to monopoly motivations, wealth effects and illegitimate exclusionary preferences may play a role in higher housing costs. See James A. Thorson, An Examination of the Monopoly Zoning Hypothesis, 72 Land Econ. 43, 55 (1996).

${ }^{165}$ See Richard Fry \& Paul Taylor, The Rise of Residential Segregation by Income, Pew Research Social and Demographic Trends (Aug. 1, 2012), http://www.pewsocialtrends.org/ 2012/08/01/the-rise-of-residential-segregation-by-income.

${ }^{166}$ This is particularly true in light of the local nature of school financing and the social and individual ill effects of concentrated poverty. See David M. Cutler \& Edward L. Glaeser, Are Ghettoes Good or Bad?, 112 Q.J. Econ. 827, 827 (1997) (concluding that blacks in segregated areas have significantly worse outcomes than blacks in integrated areas); cf. Ellickson, Social Composition, supra note 140, at 200-02 (arguing that complete integration would reduce neighborhood diversity and foreclose options for blacks to live in mostly black neighborhoods).

${ }^{167}$ See Lisa Bernstein, Opting out of the Legal System: Extralegal Contractual Relations in the Diamond Industry, 21 J. Legal Stud. 115, 115-17 (1992); see also Portes, supra note 25, at 13,15 (describing ethnic control of trades and police and fire unions).

${ }^{168}$ Durlauf \& Fafchamps, supra note 98 , at 31 . In my view, in-group solidarity may mitigate collusion between groups by increasing insularity and decreasing inter-group contact. However, if there are sufficient incentives and inter-group ties for cooperation, cohesive groups reduce the transaction costs of colluding by enabling coordination between a small number of groups rather than large numbers of individuals. In addition, structural and market conditions may allow monopoly by a single group. 
dential markets, social capital may effectuate two forms of land cartelization. In a classic cartel, owners and suppliers of housing who wish to limit competition from higher-density developments with smaller houses enforce zoning and other land use regulations to create an artificial restriction on supply and force buyers to pay more for houses. Exclusionary zoning also encompasses non-classic cartels where residents are not concerned about competition, but that smaller, higher-density housing will draw "undesirables" who will put off prospective buyers and reduce property values. ${ }^{169}$

Social capital may play a role in political organization to enact exclusionary zoning ordinances and growth controls. ${ }^{170}$ In an empirical analysis of growth controls, William Fischel found that small suburbs were more likely to have strict development and growth restrictions than larger communities. ${ }^{171}$ Fischel attributes this to the fact that in larger jurisdictions, developers have more political power while homeowners have more difficulty organizing. ${ }^{172}$ This can also be explained in social capital terms with social cohesion mediating the effect of suburb size on exclusionary zoning: In smaller suburbs, greater social cohesion may facilitate the spread of information, lower the costs of civic engagement, and recruit residents who have social ties to growth control supporters. Of course, social capital is not the sole cause of exclusionary zoning or the only possible explanation for this finding-economic incentives and other social forces matter too.

Most fundamentally, social capital facilitates the social regulation necessary to maintain and enforce zoning and growth controls. ${ }^{173}$ Exclusionary zoning is under frequent assault by developers seeking profits from higher-density construction as well as from fair housing advocates

\footnotetext{
${ }^{169}$ I thank Richard Squire for his helpful comments on classic and non-classic cartels.

${ }^{170}$ Readers may question whether Putnam's social capital — which encompasses political organization, legislation, and informal cooperation - is overbroad. I agree with that view and accordingly focus most of my attention on what I see as the heart of social capital: its role in informal collective action and quasi-formal community self-governance.

${ }^{171}$ Fischel, Small Suburbs, supra note 164, at 130 (noting that areas "whose land-use is controlled by very few jurisdictions . . . appear to be subject to the monopoly zoning effect").

${ }^{172}$ Id.

${ }^{173}$ Social capital-mediated exclusionary zoning recalls the nested institutions and polycentric regulation described in Ostrom's work: informal collective action to discriminate and exclude occurs within local and regional legal regimes. See Elinor Ostrom, Beyond Markets and States: Polycentric Governance of Complex Economic Systems, 100 Am. Econ. Rev. 641, 641-43 (2010).
} 
and occasionally state legislatures. ${ }^{174}$ Maintaining exclusionary zoning requires residents to organize, share information, and protest development plans, permit requests, and variance requests. ${ }^{175}$ Neighborhood residents also cooperate to informally ostracize undesirable entrants, including minorities and tenants, through mechanisms such as social exclusion and gossip. ${ }^{176}$ High social capital enables "NIMBYism" (not in my backyard), as Putnam has recognized, where resident factions organize committees and protests, lobby government, and in some cases pool funds to oppose locally undesirable land uses, such as halfway houses and environmental waste sites. ${ }^{177}$ In the case of affordable housing, one of the most fever-pitched settings for NIMBY opposition, dense ties and a cohesive local identity can intensify and embolden residents' opposition to the "wrong kind of people."

Social capital theory itself may justify land use protectionism. Some local comprehensive plans suggest that growth controls are necessary to maintain their community's social capital. Communities depict such efforts as "protecting our small-town character" and local stocks of social capital. ${ }^{178}$ For example, the city of Excelsior, Minnesota's Comprehensive Plan states, under the heading of "Social Capital Actions and Strategy," that the city must "[i]n all City projects and private redevelopment, consider what impact there will be on small town historic character." 179 Interestingly, the Supreme Court case upholding the constitutionality of zoning, Village of Euclid v. Ambler Realty Co., may

\footnotetext{
${ }^{174}$ See, e.g., Andrew G. Dietderich, An Egalitarian's Market: Economics of Inclusionary Zoning Reclaimed, 24 Fordham Urb. L.J. 23, 51, 65-68 (1996) (describing arbitrage profit incentives for developers to seek density variance and discussing set-asides and other state programs for affordable housing); George Lefcoe, California's Land Planning Requirements: The Case for Deregulation, 54 S. Cal. L. Rev. 447, 485-86 (1980-81) (discussing state legislative and agency efforts to compel inclusionary zoning).

${ }^{175}$ Local governments routinely employ zoning flexibility devices and grant variances, which offer case-by-case relief from zoning requirements.

${ }^{176}$ It may be that one important role of the local clubs and organizations so admired by Putnam is to signal racial, political, or religious preferences. Cf. Lior Jacob Strahilevitz, Exclusionary Amenities in Residential Communities, 92 Va. L. Rev. 437, 464-76 (2006) (describing use of amenities such as golf clubs to signal racial and other preferences). Extending this theory from amenities to local organizations, some groups, such as the Junior League and Elks for example, are strongly associated with whites.

${ }^{177}$ See Putnam, supra note 2, at 21-22 (conceding that social capital can promote NIMBYism).

${ }^{178}$ See, e.g., City of Excelsior, 2008 Comprehensive Plan, Excelsior, Minnesota 147 (2008), www.ci.excelsior.mn.us/DocumentView.aspx?DID=277.

${ }^{179}$ See id.
} 
have alluded to a social capital justification in its decision. ${ }^{180}$ The Court described apartments as a "mere parasite" on single-family neighborhoods that zoning must control or a neighborhood's "desirability as a place of detached residences [will be] utterly destroyed." 181 While the Court focused on the impact of multi-family units on open space and amenities, the opinion's impassioned tone, repeated references to maintaining the "residential character" of single-family neighborhoods, and use of the term "parasite" suggest that the Court also may have been concerned with neighborhood social fabric and cohesion. ${ }^{182}$

A remaining question is whether weak social capital channels collusion toward law, as opposed to informal action, as a lower-cost but more global and damaging means to effectuate monopoly and entrance restraints. Perhaps communities high in social capital can more easily exclude or constrain supply informally, whereas those with modest baselines of social capital find it more efficient to enact laws. If true, promoting social capital may be the lesser of two evils. While this is a plausible theory and may apply to other contexts such as racial exclusion, it is not clear that it tracks patterns of suburban exclusionary zoning. Growth controls are more common in small suburbs, which likely boast higher social capital and cohesion. ${ }^{183}$ Even if low social capital does create incentives for harmful legislation, law retains the virtues of greater visibility, placement in the public sphere of debate and norm construction, and susceptibility to external challenge and revision.

\section{Residential Property: Governing Through Social CAPITAL}

Ostrom's self-governing collectives have enticed residential property and land use scholars with their merger of pro-sociality and efficiency: Through close ties with others, people can overcome collective action problems and manage resources wisely. Yet, is this rosy picture accurate? Can we rely on social capital's positive effects to substitute in substantial share for legal and market institutions in residential property? In the past thirty years, states and localities have experimented with formal and quasi-formal neighborhood and block-level governance, piloted participatory budgeting in districts and wards, relied increasingly on resi-

\footnotetext{
${ }^{180} 272$ U.S. 365 (1926).

${ }^{181}$ Id. at 394.

182 See id.

${ }^{183}$ See Fischel, Small Suburbs, supra note 164, at 130.
} 
dents to provide public goods and neighborhood services, and witnessed the proliferation of private homeowners associations. ${ }^{184}$ Robert Nelson has advocated for a nationwide system of neighborhood associations, comparable to private homeowners and condominium associations, with the power to enact regulations, control zoning and development, and provide local services. ${ }^{185}$ Bob Ellickson and Elinor Ostrom have endorsed de-centralizing certain local governance functions to block-level and community institutions respectively, with varying degrees of legal formality. ${ }^{186}$ The work of property scholar Paula Franzese contemplates downsizing aspects of common interest community law in order to enable norms-based self-governance within private homeowners associations. ${ }^{187}$

Residential "micro-institutions" offer the advantages of local knowledge, cost-savings for local government, and, more debatably, a greater sense of personal empowerment or sub-local stake. Yet, they also entail problems and tradeoffs. Governing through social capital does not reliably safeguard against - and in some circumstances can affirmatively promote - rent-seeking, violations of individual rights, and collusion to restrain property supply. Devolving governance power, particularly regulatory and spending power, to resident groups can directly empower factions, whose members may be motivated to assume unpaid board positions and governance roles to advance their interests. Of course, the risks of collusion and rent-seeking are not limited to informal governance, but endemic to a variety of institutions. However, the idealization of governing through social capital, coupled with weaker rule of law constraints and less transparency, has made the problems of residential self-governance less apparent — and in that sense more dangerous.

Community self-governance also increases the pressure on community composition from its already substantial baseline-race, ethnicity, and

\footnotetext{
${ }^{184}$ See Archon Fung \& Erik Olin Wright, Deepening Democracy: Innovations in Empowered Participatory Government 10-12, 28 (2003) (reviewing experiments in participatory budgeting and neighborhood participation and governance); Evan McKenzie, CommonInterest Housing in the Communities of Tomorrow, 14 Housing Pol'y Debate 203, 203-07 (2003) (describing rise of common interest community housing).

${ }^{185}$ Robert H. Nelson, Private Neighborhoods and the Transformation of Local Government 259-78 (2005) [hereinafter Nelson, Private Neighborhoods].

${ }^{186}$ See Ellickson, New Institutions, supra note 19, at 82-85 (proposing block-level associations); Ostrom, supra note 173, at 656-58, 664-65 (2010) (describing successful management of natural resources by farmers, residents, and other groups and endorsing non-state resource governance in some situations).

${ }^{187}$ See Franzese, supra note 19, at 591-92.
} 
other class-based characteristics are often misapplied proxies in this process. When owners benefit from limiting congestion rather than allowing widespread access or participation, coordination costs are high, and interpersonal cooperation is vital, they will try to attract entrants perceived to have the strongest tastes for contribution and capacity to integrate into a cohesive group. Without some ability to predict the behaviors, preferences, and interests of others, the costs of governing through social capital skyrocket. These dynamics ratchet up preferences for homogeneity among existing residents and dissuade minority newcomers who face increased hostility and risk of unequal status and participation. In the scholarship on residential commons, legal scholars gloss over this issue, noting seemingly without upset that "homogenous groups" typically experience greater success in producing local goods and require less government intervention. ${ }^{188}$ Yet, should we accept governing by homophily in the service of social capital?

This "logic of homogeneity" may also be at work in Ostrom's famous examples of natural resource commons. ${ }^{189}$ Admittedly, it is difficult to parse the relative contributions of culture, often machismo culture, from the homogenizing influence of social capital-fueled commons governance. Nonetheless, the striking trend toward ethnic exclusion is noteworthy. Informally managed fishing grounds are often ethnically homogenous and community-managed acequias (irrigation ditches) in New Mexico routinely employ gossip and social sanctions to keep water rights from Anglo "newcomers" and within families and communities. ${ }^{190}$ In his account of the Maine lobster gangs, James Acheson describes how the gangs, replete with social capital, harassed and cut the traps of entrants based in part on their ethnicity - even Italian and Canadian backgrounds were not sufficiently mainstream. ${ }^{191}$ The "kings" or leaders of the lobster gangs also opposed "blacks, ... hippies, welfare [recipients],

\footnotetext{
${ }^{188}$ See Foster, supra note 64, at 91-92.

${ }^{189}$ Carol Rose has criticized Ostrom's commons for their propensity for rigid hierarchies, sexism, or other non-egalitarian norms. See Rose, supra note 29, at 33-34.

${ }^{190}$ Telephone Interview with Michael Cox, Assistant Professor, Dartmouth Coll. (Oct. 2, 2012); Telephone Interview with José A. Rivera, Professor, Univ. of N.M. (Oct. 5, 2012).

${ }^{191}$ James M. Acheson, The Lobster Gangs of Maine 69 (1988). There are also barriers for female lobster fishermen, though the 2007 recession has lowered the "glass gangway" as reduced profits have dissuaded young men. Chris Arnold, She's No Man; She's a Lobsterman, Nat'l Pub. Radio (Aug. 19, 2012, 2:19 AM), http://www.npr.org/2012/08/19/159175781/ fishing-for-lobsters-not-just-a-mans-game.
} 
Russians, Jews, bureaucrats, Arabs, and Iran[ians]." ${ }^{192}$ Entrance is tightly controlled in these communities: in the traditional lobster gangs a boy "inherits a place in his father's gang," and outsiders, without close affiliations to the community or gang, find entry difficult, if not impossible. ${ }^{193}$ While member selection is formally absent from Ostrom's design principles for community-governance, her writing describes common culture and "rules of the game" as requisite to successful community self-governance - indeed, in some accounts shared culture is part of the definition of social capital. ${ }^{194}$

Some legal scholars and social capitalists have wrongly assumed that social capital, properly nourished through participation and selfgovernance, will reduce factions and exclusionary harm. ${ }^{195}$ This misconception (and some of the appeal of social capital itself) hearkens to the anti-federalist idea of civic virtue as the solution to factions. The antifederalists emphasized decentralization in small communities that would enable the type of interaction necessary to promote civic virtue or "public happiness." 196 They championed deliberation and participation in town meeting style government to educate citizens in civic virtue and restrain self-interested factions from subverting the greater good. ${ }^{197}$ However, the anti-federalists recognized the tension between intensive self-governance and diversity: Their model of deliberation and civic virtue explicitly required community homogeneity in terms of wealth, education, and power. ${ }^{198}$

If Elinor Ostrom showed that individuals can resolve collective action problems absent legal or government institutions, the legal scholarship has not resolved when, or whether, governing by social capital should

\footnotetext{
${ }^{192}$ Acheson, supra note 191, at 61.

${ }^{193}$ Id. at 65-68; see also Clark C. Gibson \& Tomas Koontz, When "Community" Is Not Enough: Institutions and Values in Community-Based Forest Management in Southern Indiana, 26 Hum. Ecology 621, 639-40 (1998) (describing how community-managed forest residential community required members to vouch for and pay the debts of applicants during a five-year waiting period).

${ }^{194}$ See Elinor Ostrom, Crafting Irrigation Institutions: Social Capital and Development 24-25, 29-30 (1990) (noting failure of commons with "individuals coming from different regions ... and ethnic and religious backgrounds" because "[no] social capital exists").

${ }^{195}$ See Putnam, supra note 2, at 23; Franzese, supra note 19.

${ }^{196}$ For a description of the anti-federalist case, see Cass R. Sunstein, Interest Groups in American Public Law, 38 Stan. L. Rev. 29, 35-38 (1985).

${ }^{197}$ See Herbert J. Storing, What the Anti-Federalists Were For 43-45 (Murray Dry ed., 1981).

${ }^{198}$ Sunstein, supra note 196 at 36.
} 
play this role in residential property. ${ }^{199}$ My account of social capital provides a more critical view of residential self-governance, and underscores the need for a substantial overlay of law, as well as other political and institutional supports, to channel local collective action to socially desirable means and ends. In a similar vein, scholars such as Carol Rose and Sheila Foster have suggested the need for a minimal level of law and government involvement to mitigate inegalitarianism and free-riding in the commons. ${ }^{200}$ To make my analysis more concrete, the following Sections consider proposals and initiatives in neighborhood direct democracy, block-level associations, and common interest communities.

\section{A. Assessing Neighborhood Direct Democracy and Block Associations}

Across the country, a number of neighborhood direct democracy initiatives have transferred regulatory responsibilities and service provision to neighborhoods with the vision of resident self-governance bolstering struggling urban areas. ${ }^{201}$ The Minneapolis Neighborhood Revitalization Program ("NRP"), the most radical experiment in direct neighborhood democracy to date, provided twenty million dollars per year for neighborhoods to form neighborhood associations, vote in boards, and create and implement neighborhood action plans for affordable housing and other revitalization efforts. ${ }^{202}$ The NRP envisioned that neighborhood groups would build social capital that would enable them to realize city planning goals with lower costs and higher resident satisfaction. ${ }^{203}$ On balance, the Minneapolis NRP realized some significant successes. There were, however, tradeoffs to neighborhood democracy that have been neglected in the enthusiasm for grassroots governance. While the NRP worked relatively well in homogenous neighborhoods, Edward G.

\footnotetext{
${ }^{199}$ Ostrom's self-governing natural resource commons are often found in countries with unstable or inadequate markets, legal institutions, and financial resources that make selfgovernance attractive or necessary.

${ }^{200}$ See Foster, supra note 64, at 89-90; Rose, supra note 29, at 44.

${ }^{201}$ See Leighninger, supra note 78 , at 5-6. See generally Section I.A.

${ }^{202}$ Sarah Elwood, Neighborhood Revitalization Through 'Collaboration': Assessing the Implications of Neoliberal Urban Policy at the Grassroots, 58 GeoJournal 121, 124 (2002).

${ }^{203}$ The NRP Policy Board goals describe, "When people organize, collect and analyze information, and become more knowledgeable about their community, they can be significant contributors to the revitalization of their neighborhood .... Neighborhood revitalization ultimately depends on a sense of neighborhood identity..." See NRP, NRP Primer, http://www.nrp.org/r2/aboutnrp/Basics/Primer.html (last visited Apr. 9, 2013); see also Nelson, Private Neighborhoods, supra note 185, at 269; Elwood, supra note 202, at 126-27.
} 
Goetz and Mara S. Sidney describe how in majority-tenant, racially and economically diverse neighborhoods, white homeowners rapidly coordinated to constrict housing supply and exclude "undesirables" by halting rehabilitation of multi-family buildings, gutting a nationally recognized program of leasehold cooperatives, and funding conversions of rentals to homes. ${ }^{204}$ In some areas, a hefty chunk of the NRP money funded grants and subsidized loans to individual homeowners for home remodeling. ${ }^{205}$

Implicit bias and endogenous social dynamics no doubt influenced neighborhood governance in the Minneapolis NRP, where white homeowners dominated boards and black homeowners, non-profits, and tenants who wished to participate were often shut out. ${ }^{206}$ However, status may have also played a pivotal role because of the pressures of collective governance. The NRP required residents to self-organize and learn local government functions with relatively thin legal frameworks and limited institutional supports. Inegalitarianism may proliferate within institutions that govern through social capital in part to reduce the overwhelming costs of coordination. Social status lowers the costs of collective action by determining entrance and distributing authority and tasks with quick and dirty, widely understood allocation rules. ${ }^{207}$ In a sense, this tracks the unasked question in the Demsetz account of why property rights emerge: How do people go about the process of setting up a prop-

${ }^{204}$ Edward G. Goetz \& Mara S. Sidney, The Impact of the Minneapolis Neighborhood Revitalization Program on Neighborhood Organizations 11-12 (1994); see also Elena Fagotto \& Archon Fung, Empowered Participation in Urban Governance: The Minneapolis Neighborhood Revitalization Program, 30 Int'l J. Urb. \& Regional Res. 638, 645 (2006) (describing how property and business owners opposed the use of NRP funds for subsidized housing).

${ }^{205}$ One of the goals of the NRP was to improve housing, so grants to individual owners were not outside the program's scope or expectations. However, the volume and value of these grants suggest some degree of rent-seeking. One independent review concluded that eighty percent of households assisted by the twenty million dollars in annual funds were used to assist homeowners. See Jennifer Turnham \& Jessica Bonjorni, Review of Neighborhood Revitalization Initiatives 38-39 (2004), available at http://www.nw.org/network/ pubs/studies/documents/revitalizationReview.pdf.

${ }^{206}$ Low-income residents often lacked the resources, expertise, and campaign power to win board positions, or lacked the social ties to assume committee positions. See Goetz \& Sidney, supra note 204, at 27-29.

${ }^{207}$ There has been a recent wave of research on the use of status to overcome collective action problems, but it focuses on how collective action contribution increases social status and how free-riding decreases it. See Brent Simpson et al., Status Hierarchies and the Organization of Collective Action, 30 Soc. Theory 149, 158 (2012) (reviewing research on reputational gains from contribution to collective action and proposing that social status sequences and coordinates collective action). 
erty system? Systems may, and often do, focus on first in time (earlier entrants), prior property holdings, contribution to the group, experience, or skill. But, frequently overlooked is the role of ex ante social status, often proxied by characteristics such as race, gender, and social class, to coordinate property rules and allocate roles and tasks. ${ }^{208}$

In light of the costs and pitfalls of governing through social capital, I favor a more cabined role for neighborhood direct democracy programs, with more limited grants of power and spending authority, robust institutional frameworks, enhanced political process protections, and in some cases mandatory inclusion of non-profit and advocacy groups on governance boards. Compared to bold initiatives like the NRP, there is greater promise in more modest devolutions that utilize existing local government infrastructure and thicker institutional constraints. For example, several cities have piloted participatory budgeting where local government organizes a group of neighborhood residents and community non-profits to propose ways to spend a limited, often modest, fund for public infrastructure improvements and residents vote on the proposals. $^{209}$

My analysis also has implications for prominent scholarly proposals for neighborhood and block-level associations in older neighborhoods that lack private homeowners associations. Bob Ellickson has advocated creating block improvement districts ("BLIDs") with narrow grants to provide supplementary services, such as landscaping and street cleaning, and to relax zoning restrictions. ${ }^{210}$ In my view, the risks of governing through social capital underscore the prudence of Ellickson's limited grant of power to BLIDs to provide supplementary services and his proposals for supermajority voting and legal safeguards. ${ }^{211}$ I am skeptical, however, of Ellickson's related proposal for special Regulatory Block Improvement Districts ("RBLIDs") with regulatory and zoning power and, more so, of Robert Nelson's call for a nationwide system of neigh-

\footnotetext{
${ }^{208}$ Notably, such systems may tend toward rigidity because mobility will create confusion about governance authority and muddy the status rules themselves.

${ }^{209}$ Residents in Chicago Ward 49 voted on how to spend a limited pool of infrastructure improvement funds (approximately one million dollars) following an extensive process that included the involvement of over fifty community groups to develop and oversee the participatory process. See Alderman Joe Moore, Participatory Budgeting, http://www.ward49.com/ participatory-budgeting (last visited Apr. 9, 2013).

${ }^{210}$ See Ellickson, New Institutions, supra note 19, at 96-99.

${ }^{211}$ See id. at 97-98, 103, 104 (proposing supermajority vote for BLID establishment and application of common interest community law).
} 
borhood associations to regulate land development and zoning, provide core services including police, and assume ownership of city streets, parks, and facilities. ${ }^{212}$ The small scale of the neighborhood and especially the block increases the ease with which both social capital and factions develop, as Ellickson seems to intuit in his enumeration of voting and legal protections for BLIDs. ${ }^{213}$ Devolving regulatory and spending power directly to residents enhances the power of homeowner factions relative to developers and tenants (some of these proposals do not allow resident tenants to vote), and can increase cartel-like restrictions on housing supply. ${ }^{214}$ As the Minneapolis NRP experience reveals, there is a substantial risk that urban neighborhood self-governance will displace tenants, many of whom live in city neighborhoods as result of exclusionary zoning and the resulting dearth of suburban rental apartments.

\section{B. Common Interest Communities: Condominiums, Co-ops, and Homeowners Associations}

Self-governing private residential communities, such as homeowners associations, condominiums, and co-ops, presumably should be incubators of positive social capital. Yet, high expectations for the realization of community and democracy have given way to conflict, litigation, and controversies over secession from public life. ${ }^{215}$ Disputes over noise, dogs, cars, and garbage are common and call into question the assumption that social capital will encourage beneficial norms and secure cooperation. $^{216}$ To the contrary, self-governance may intensify residential

\footnotetext{
${ }^{212}$ See Nelson, Private Neighborhoods, supra note 185, at 259-68; Ellickson, New Institutions, supra note 19, at 99-100; Robert H. Nelson, Privatizing the Neighborhood: A Proposal to Replace Zoning With Private Collective Property Rights in Existing Neighborhoods, 7 Geo. Mason L. Rev. 827, 833-34, 873 (1999) [hereinafter Nelson, Existing Neighborhoods].

${ }^{213}$ See Ellickson, New Institutions, supra note 19, at 97-99, 103-04.

${ }^{214}$ It is not clear that developers will be as powerful in these micro-institutions for a variety of reasons: unlike local government officials, homeowners' interests are narrowly focused on their particular neighborhood or block and the common developer exaction of land or development in another part of town will not be of interest to RBLIDs or neighborhood associations. With respect to voting, Nelson's proposal does not allow for tenant voting. See Nelson, Existing Neighborhoods, supra note 212, at 834. Ellickson's limited grant BLID does not allow tenant voting, but his regulatory RBLID requires approval by supermajorities of owner and residents. Ellickson, New Institutions, supra note 19 at 99-100.

${ }^{215}$ See Evan McKenzie, Privatopia: Homeowner Associations and the Rise of Residential Private Government 26, 135 (1994).

${ }^{216}$ See Domini Hedderman, Managing Conflicts Among Neighbors, N.J. Cooperator, Feb. 2007, http://njcooperator.com/articles/31/1/Managing-Conflict-Among-Neighbors/Page1.
} 
discord. ${ }^{217}$ In a recent survey of common interest communities ("CICs") in Massachusetts, $64 \%$ of boards reported being threatened with at least one lawsuit in the past five years and $22 \%$ were currently in litigation. ${ }^{218}$ Research by Henry Hansmann, and more recently by Michael Schill, finds that co-operatives, a form of common interest community with more intensive self-governance and common property than condominiums, trade at a sizeable discount to similar condominiums. ${ }^{219}$ Efficiency and welfare losses from collective self-governance of common property, among other factors, appear to be capitalized into lower co-operative sale prices. ${ }^{220}$ This analysis reveals a problem unresolved by social capitalists: the proximity and interdependency that purportedly foster social capital also breed conflict about uses, upkeep, and resident behavior. ${ }^{221}$ The predominant force resolving these conflicts is not social capital, but the growing use of professional management agents. ${ }^{222}$

In a thought-provoking article, Paula Franzese has proposed that common interest communities have greater legal free rein in order to

html. A California attorney described fistfights and other physical violence among residents or between residents and resident-board members as "not uncommon." Debora Vrana, The Runaway Power of Homeowners Associations, MSN Real Estate, http://realestate.msn. com/article.aspx?cp-documentid=13107752 (last visited Mar. 14, 2013).

${ }^{217}$ Admittedly, it is difficult to draw firm conclusions as empirical study has been limited and frequently undertaken by interested parties, such as trade associations for common interest communities.

${ }^{218}$ Courtney L. Feldscher, Managing Conflict in Community Associations: The Who, What, Where, When, and Why 10 (unpublished manuscript), available at http://www. cairf.org/scholarships/feldscher_study.pdf (independent study of community associations).

${ }^{219}$ See Henry Hansmann, Condominium and Cooperative Housing: Transactional Efficiency, Tax Subsidies, and Tenure Choice, 20 J. Legal Stud. 25, 68 (1991) (concluding that the condominium form is somewhat more efficient than the cooperative form and requires a smaller subsidy to make it competitive with rental); Michael H. Schill et al., The Condominium Versus Cooperative Puzzle: An Empirical Analysis of Housing in New York City, 36 J. Legal Stud. 275, 309 (2007) (finding that cooperatives trade at a 13.4 percent discount to condominiums). Hansmann also concludes that tax subsidies for ownership and rent control encouraged the spread of condominiums and cooperatives despite the fact that rental is the more efficient regime. See Hansmann, supra, at 69.

${ }^{220}$ In addition, shared mortgage risk and restraints on resale (for example, co-op interview requirements) reduce co-op value.

${ }^{221}$ Moreover, governance by one's peers poses its own problems. As one attorney observed, "When you have a neighbor being put in charge of you, it just breeds resentment." See Vrana, supra note 216 (internal quotation marks omitted).

${ }^{222}$ The role of management agents, much neglected in property law, appears key to providing an intermediary and a coordinator who acts in a professional, non-peer role. See Henry Hansmann, The Ownership of Enterprise 222 (1996) (noting growth of management firms). 
promote, and capitalize upon, their social capital. ${ }^{223}$ In her view, social capital is better nourished by a less heavy-handed legal framework than the current panoply of state laws, conditions, covenants, and restrictions ("CC\&Rs"), and community rules. ${ }^{224}$ She recommends paring the common interest community legal declaration to a few core rules integral to the community's structure and allowing social capital to take root before considering additional rules, as well as limiting association intervention to nuisance-like activities. ${ }^{225}$ Franzese's point is well taken that poor design and legal excess hinder common interest communities. However, while some culling may be beneficial, I do not believe dramatically downsizing formal law in favor of informal self-governance will ameliorate conflicts within these communities.

As a threshold matter, it is an unanswered empirical question whether common interest community laws impede or foster positive social capital. Cross-country research by Frank Cross suggests that in some contexts law can increase trust by providing assurances and incentives for trustworthy behavior. ${ }^{226}$ In later work, it seems Franzese agrees, as she subsequently proposes more substantial legal protections for common interest communities to promote trust. ${ }^{227}$ In my view, reducing common interest community law to a minimal core increases opportunities for rent-seeking. Supermajority voting requirements for amending key governance provisions, thick legal protections, and perhaps even the complexity of common interest community rules create if not formal checks and balances, at least obstacles to radical redistribution at the hands of resident factions (factions on the board are less constrained under some CIC governing laws). ${ }^{228}$ In addition, state law, CC\&Rs, and associational

\footnotetext{
${ }^{223}$ See Franzese, supra note 19, at 589-91.

${ }^{224}$ See id at 591 .

${ }^{225}$ See id. at 591-92.

${ }^{226}$ See Cross, supra note 128 , at 1460.

${ }^{227}$ See Paula A. Franzese \& Steven Siegel, Trust and Community: The Common Interest Community as Metaphor and Paradox, 72 Mo. L. Rev. 1111, 1139-47 (2007) (recommending sunsetting developer-imposed servitude regimes to enable communities to select from regulatory "templates" and adopting more homeowner protections).

${ }^{228}$ Franzese's desire to limit the board's power seems to recognize the threat that selfinterested members will assume unpaid board positions or that social capital will develop over time between board members and motivate rent-seeking or illiberalism. See Franzese, supra note 19, at 591. However, narrowly circumscribing board authority also limits the board's power to address damaging spillovers of social capital and other conflicts among residents.
} 
rules may have some degree of expressive value and communicate rule of law expectations to members and boards.

Common interest communities also confront exclusionary proclivities and incentives to reduce the costs of self-governance through homogeneity, often proxied by class-based characteristics. ${ }^{229}$ Reducing rules to a minimal core increases the pressure on self-governance and the already substantial demand for homogeneity. The limited reach and enforcement of the federal Fair Housing Act, and some state fair housing statutes, do not provide adequate redress. ${ }^{230}$ Accordingly, CIC laws that inhibit excessive development, or undesirable deployment, of social capital may have substantial public value.

In closing, governing residential property through social capital, absent substantial institutional safeguards, may be an uneasy fit for developed and diverse societies. Perhaps these issues are part of the reason why residential self-governance in the United States often does not look much like Ostrom's commons at all. Despite the popular enthusiasm for grassroots governance, local micro-institutions often have limited powers and substantial legal constraints, and in some cases, such as Boston's famous Dudley Street Initiative, extensive support from government and non-profit institutions. ${ }^{231}$ At the end of the day, governing through social capital in residential micro-institutions is neither the apogee of civic communitarianism nor the apocalypse of pluralism. It is an inexorable part of the cost-savings necessitated by federal devolution and more limited fiscs for states and cities. And for my purposes, it is a point of reflection for the misguided expectations for social capital.

\footnotetext{
${ }^{229}$ As Henry Hansmann observes, "[C]onflicts among members are a serious problem in the governance of cooperatives and condominiums ... [and] homogeneity of membership is an important aid to viability." Hansmann, supra note 222, at 201; see also Lior Jacob Strahilevitz, Information Asymmetries and the Rights to Exclude, 104 Mich. L. Rev. 1835, 185859 (2006) (describing the exclusionary proclivities of common interest communities and their use of "exclusionary amenities" such as golf clubs or Catholic universities to signal their preferences for residents). For other accounts of preferences for residential exclusion, see McKenzie, supra note 215, at 60-78; Reynolds Farley \& William H. Frey, Changes in the Segregation of Whites from Blacks During the 1980s: Small Steps Toward a More Integrated Society, 59 Am. Soc. Rev. 23, 28-29 (1994).

${ }^{230}$ See Fair Housing Act, 42 U.S.C. $\S \S 3601-3619,3631$ (2006); John Yinger, Sustaining the Fair Housing Act, 4 Cityscape 93, 98 (1999) (describing the history of the Fair Housing Act and the underlying political compromises that led to an "almost ludicrous" lack of federal enforcement authority and capacity).

${ }^{231}$ See Elizabeth A. Taylor, Note, The Dudley Street Neighborhood Initiative and the Power of Eminent Domain, 36 B.C. L. Rev. 1061, 1077-81 (1995).
} 


\section{Residential Norms, Social CAPITAL, AND SMall RePubliC THINKING}

Using property law to promote social capital would be less troubling if we could predict that the instrumentality of social capital would be reliably coupled with positive residential norms that would restrain dark side dynamics. As discussed previously, social capital alone does not offer built-in constraints on bad behavior. In the residential context, civic republican ideals cling to property, but imperfectly (some scholars have suggested near-schizophrenically) ${ }^{232}$ and often faintly when one is contemplating her own residential property rather than her perceptions of others' obligations vis-à-vis their property. These shortcomings of public-minded sensibility in residential property are implicit in the vigorous efforts of property scholars such as Gregory Alexander and Eduardo Peñalver to inculcate and disseminate public-regarding property norms. ${ }^{233}$ Anemic other-regarding residential norms create a substantial risk of harm from social capital, particularly with respect to restraining housing supply and entrance. Contrary to Madison, the problem of factions acting against the public good may not be due to small republics so much as small republic thinking.

This point is most precisely understood through the sociological theory of roles. Roles entail shared norms for a given social position that define the expected behavior of the role-holder. ${ }^{234}$ In the constitutional arena, Bruce Ackerman has conceptualized mixed public citizen and private citizen roles and explored their importance to a dualist Constitution. ${ }^{235}$ In the residential context, the combination of private and public orientations and activities appears to produce a mixed public- and privateregarding residential property role. Commitments to equality, altruism, or public citizenship ideals matter somewhat or sometimes. One can point to examples of local action with respect to climate change or hu-

${ }^{232}$ See Carol M. Rose, Mahon Reconstructed: Why the Takings Issue Is Still a Muddle, 57 S. Cal. L. Rev. 561, 561-62 (1984) (discussing how civic republican and economic perspectives stratify takings jurisprudence).

${ }^{233}$ See Gregory S. Alexander, The Social-Obligation Norm in American Property Law, 94 Cornell L. Rev. 745, 760-73 (2009); Eduardo M. Peñalver, Property as Entrance, 91 Va. L. Rev. 1889, 1963-64 (2005).

${ }^{234}$ See Ralph H. Turner, Role Theory, in Handbook of Sociological Theory 233, 233-34 (Jonathan H. Turner ed., 2001).

${ }^{235}$ See Bruce Ackerman, We the People: Foundations 232-35 (1991). 
man rights. ${ }^{236}$ Also, abundant social capital may carry fewer negative externalities when the residential norm or role sub-type relates to certain kinds of local public institutions. For example, local public (albeit limited-access) institutions such as schools and parks may orient residents toward public-mindedness, at least with respect to these activities or "sub-roles" (though notably any public citizenship attached to schools has not secured de facto school desegregation). On balance, however, the residential property role remains strongly local group-regarding and private-regarding. It is more private-spirited and insular than how one might conceive one's role as a student or an African American or a national voter. The residential owner role in particular comprises a perceived prerogative to exert control over housing supply and the social composition of residents.

Residential property norms are strongly, though not exclusively, rooted in the economics of residential ownership. Homeowners, as William Fischel has described, have a strong motivation to maintain and enhance the value of their large, undiversified assets: their homes. ${ }^{237}$ This excessive ownership stake encourages local investments that increase property values, including beneficial contributions to schools and environmental quality as well as harmful investments in racial exclusion and exclusionary zoning. ${ }^{238}$ It seems possible, even probable, that this defensiveness of self-interest in one's residential property fails to update in perfect Bayesian fashion and instead generalizes to a degree to other property contexts, including public residential contexts. These norms may spill over to affect tenants, albeit more weakly.

Historical patterns of land collusion and exclusion also affect norms of residential property behavior. Exclusionary zoning has been well established for decades and sanctioned by the Supreme Court. ${ }^{239}$ Given the reinforcement of these norms through weak state and federal laws, it is not surprising that land cartelization and NIMBYism are littlequestioned aspects of residential life. With respect to racial and ethnic exclusion, there is a historical resonance to subordinating individual

\footnotetext{
${ }^{236}$ See, e.g., Taking the Local Road to Copenhagen: ICLEI USA's Primer on the Role of Local Governments in an International Climate Agreement, ICLEI Loc. Gov'ts for Sustainability USA, http://www.icleiusa.org/action-center/affecting-policy/international-policy-re sources/taking-the-local-road-to-copenhagen (last visited Feb. 1, 2013).

${ }^{237}$ See Fischel, supra note 31, at 3-19, 281.

${ }^{238}$ See id.

${ }^{239}$ See Vill. of Euclid v. Ambler Realty Co., 272 U.S. 365, 394-96 (1926).
} 
equality to residential property rights, the rhetoric of community, and local property values. Neighborhood associations and resident cooperation are strongly associated with their long history of extra-legal and legal maintenance of segregation. ${ }^{240}$ Indeed, exclusion may be one of the more resonant ways that communities conceive of and experience collective action.

These tendencies are exacerbated by the fact that for homeowners, who represent a majority share of the national population, ownership is conceptualized as a civic moment. Longstanding and influential sentiments dating to Jefferson and civic republicanism aver a corporeal land stake in the country as a cultivator of civic capacity. ${ }^{241}$ According to Jefferson and other influential thinkers, property makes individuals trustworthy as democratic citizens and voters by assuring independence and developing their civic faculties. ${ }^{242}$ Thus, it may be that with respect to national or public citizenship, property ownership allows some resting on your laurels - by becoming a property owner one has already discharged an important act of public citizenship. There is also an intuition, correct in some contexts but not in others, that contributing to one's local community substantially fulfills obligations to the national good. Resident provision of certain local goods does enable government savings by shifting costs and service responsibilities to citizens. However, this is a more modest contribution than the popular understanding of local activity and property ownership as realizing citizenship and democracy. $^{243}$

\footnotetext{
${ }^{240}$ See Loewen, supra note 142; Sugrue, supra note 143, at 215-25.

${ }^{241}$ See Letter from Thomas Jefferson to John Adams (Oct. 28, 1813), in The Life and Selected Writings of Thomas Jefferson 632-34 (photo. reprint 1946) (Adrienne Koch \& William Peden eds., 1944); Stern, supra note 80, at 922-25 (detailing civic republican virtues attributed to ownership).

${ }^{242}$ As Jefferson explained:

Here [in America] every one may have land to labor for himself . . . Every one, by his property, or by his satisfactory situation, is interested in the support of law and order. And such men may safely and advantageously reserve to themselves a wholesome control over their public affairs, and a degree of freedom, which, in the hands of the canaille of the cities of Europe, would be instantly perverted to the demolition and destruction of everything public and private. Letter from Thomas Jefferson to John Adams, supra note 241, at 633.

${ }^{243}$ In light of the subsidies for homeownership and the social contribution of tenants, the benefits from ownership and homeowners' social contribution may be less than assumed. See Stern, supra note 80 , at 929-32.
} 
Today, social capital plays a similar role in cultural thought by reifying orientations toward individualistic or small republic thinking with the inflated promise that group action yields national dividends. Social capitalists allege that cooperating to advance private or local self-interest in a group bound by social ties, trust, and norms of reciprocity creates positive spillovers for national democracy, economy, and citizen flourishing. ${ }^{244}$ In the context of local working together, we can be less concerned about our obligations to the welfare of others, at least others beyond our group, because our very cooperation produces societal benefits. Social capital theory thus entrenches private-regarding norms by eliding a balancing between broader social benefits and local group interests and claiming that action to advance the latter will provide the former. This is perhaps the local resident version of "doing well by doing good."

If self- or local-focus is largely due to economic incentives and historical determinants, one might question whether it matters if social capital and small republic thinking suppress civic virtue that would not find expression regardless. This view neglects the noisiness and variability to whether negative spillovers and collusion occur, based on the sum of factors such as transaction costs, political influence, the magnitude of the risk or effect on property values, the availability of explicit or implicit compensation, and residential norms. In addition, to the extent that social capital advances a norm-neutral approach and encourages complacency toward broader social obligations, it may forestall positive normative changes that would be capitalized into home prices and thereby lessen negative homeowner dynamics. For example, as prejudice against black entry into majority-white communities decreases through social movements and norm change, drops in housing prices from black residents should also decrease, further attenuating homeowner opposition. ${ }^{245}$ These normative changes may be slower to occur in an age of social capital thinking that elevates residential gemeinschaft to noble civic purpose and depicts local, private-regarding activity as public citizenship.

\footnotetext{
${ }^{244}$ See Putnam, supra note 2, at 288-89.

${ }^{245}$ See Bobo \& Zubrinsky, supra note 160, at 885-87 (1996).
} 


\section{BEYOND GEMEINSCHAFT PROPERTY}

The promise of social capital is its capacity to resolve prisoners' dilemmas. Communities are better off when residents cooperate to clean up parks, refrain from littering, and "keep eyes on the streets." 246 The classic prisoners' dilemma is two prisoners who are jointly best off by cooperating to remain silent but face incentives to defect and secure lighter sentences by unilaterally confessing. The prisoners' dilemma illustrates how individuals acting rationally to advance their self-interest may, as a group, end up worse off. Of course, as any economist recognizes, resolving the prisoners' dilemma maximizes the prisoners' joint utility but does not speak to whether society would be better off if the prisoners (let us assume they murdered innocent bystanders) remained in prison. More precisely, the value of social capital to prisoners' dilemmas in residential property relies on the assumption that there are limited negative externalities from cooperation or the precursors to cooperation.

This Article questions that assumption in light of historical and modern-day examples of residential social capital. Many property scholars have aligned with social capitalists in the mission of promoting social capital through property law and property institutions through social capital. $^{247}$ They endorse the view that property law and institutions should produce local social capital by encouraging social interaction, increasing ownership, raising the costs of exit, and devolving governance responsibilities to resident groups as "incubators of local social capital. ${ }^{, 248}$ These accounts neglect the risks and costs of abundant local social capital and vesting control of property in solidaristic mini-societies. The local civil society of bonding social capital is an internally cohesive but nationally fragmented social structure that can close off property, fuel factions and cartels, and dilute orientations toward national interests and the public good. Cohesive social capital can also limit information diffusion, suppress innovation, and chill dissent and non-conformity. ${ }^{249}$ And if communities must be tight-knit, gemeinschaft enclaves to prosper, then similarity and social proximity are the coin of the realm.

\footnotetext{
${ }^{246}$ I thank Bob Ellickson for his helpful comments and questions on this point.

${ }^{247}$ See supra Section I.A.

${ }^{248}$ Ellickson, New Institutions, supra note 19, at 83-84. See generally supra Section I.A.

${ }^{249}$ See Levi, supra note 118, at 51-52 ("Historically, there is reason to believe that maintenance of close networks blocks innovation and reinforces traditionalism, generally in the form of closed economies." (footnote omitted)); Portes, supra note 25, at 15-16.
} 
To be clear, my claim is not that the rotary club should be stricken from the local landscape, neighbors should structure their relations within formal rules, or that participatory local government initiatives and community-building are inevitably harmful. Indisputably, the constituent elements of social capital have value in some contexts. Social interaction and informal regimes of sharing information and resources can convey benefits to participants and to society. Certain types of social capital lower the costs of political organizing. Social institutions, norms, and conventions fill gaps within laws (and in some cases are law, properly defined). It may be that social capital is more productive in contexts other than residential property, such as schools or families, where norms and roles are better aligned with social welfare enhancement, substitutes for social capital are scarce, or self-governance is critical to personal or social identity. In the residential setting, perhaps social capital is best understood as necessary but dangerous. Some baseline of social capital, or at least some of its constituent elements, is necessary to residential life. But excessive bonding capital or social capital tethered to bad norms can wreak substantial harm.

If social capital is to retain a role in property law we must disaggregate its component parts and consider their individual utility in specific residential contexts. I offer some preliminary thoughts here. Many of the elements of social capital, such as social ties, particularized trust, civic engagement, participation, and shared norms, can be employed for good or ill. To develop useful legal constructs, we must turn to the task of particularizing these concepts and animating them with normative content. Examples include norms of respecting personal property or Robert Sampson's research on diffuse norms of neighborhood social regulation. $^{250}$ Disaggregation also necessitates context-specific analyses: the scale and nature of the desired collective action affect the value of various elements of social capital. For example, research suggests that local friendship ties increase neighborhood social cohesion but not participation in public events or willingness to address extra-local social problems. ${ }^{251}$ Perhaps the most intriguing and promising aspect of social capital for residential property is the development of generalized trust (the belief that strangers can generally be trusted). Generalized trust creates

\footnotetext{
${ }^{250}$ I thank Daniel Markovits for his comments about norms of respecting personal property. For more detail on norms of local social regulation, see Sampson, supra note 36, at 17172 .

${ }^{251}$ See id. at $216-17$.
} 
the preconditions for broad social exchange, minimizes the need to make provisions to control opportunistic behavior, creates fewer negative externalities than in-group trust or social ties, and has the potential to open residential communities. ${ }^{252}$ In his empirical study of law and trust, Frank Cross contends that law can serve as a bridging tie that promotes social trust. ${ }^{253}$ Of course, promoting generalized trust is not invariably successful or positive. ${ }^{254}$ For example, generalized trust is both reciprocal to and reliant on trustworthiness (without a substantial level of trustworthiness in the population, generalized trust will not develop, and if it does it will make residents vulnerable to deceit and trickery).

The balance of this Part considers the role of formal law and then turns to potential objections to my account of social capital's dark side in residential property. I save the constructive task of developing typologies of social capital harm and corresponding legal correctives for future work. My contention here about law and social capital is plain: the chief role of property law is not to promote social capital, at least in its aggregate form, but to address its negative spillovers and illiberal effects. Carol Rose apprehends these concerns in her argument for a modest overlay of egalitarianism-protecting law in property commons. ${ }^{255} \mathrm{In}$ my view, the need for law to support and constrain residential selfgovernance and local social capital applies with substantial force, and somewhat thicker legal institutions, than envisioned by Rose and certainly Dagan and Heller. ${ }^{256}$

Some aspects of the role of law in addressing social capital's dark side should not be controversial. Most social capitalists would support legal protections against discrimination, such as the Fair Housing Act.

${ }^{252}$ See Bo Rothstein \& Dietlind Stolle, The State and Social Capital: An Institutional Theory of Generalized Trust, 40 Comp. Pol. 441, 441-43 (2008) (finding that experiences with street-level bureaucrats in order-maintaining and public welfare government institutions affect generalized trust).

${ }^{253}$ See Cross, supra note 128, at 1522-27, 1542 ("'T] he law . . can enhance bridging social capital, increasing the total level of trust in society and preventing some of the discriminatory effects of trust.").

${ }^{254}$ Notably, there is emerging evidence that high generalized trust may decrease the development of norms of social order, specifically citizen readiness to obey laws and regulations. See van Deth \& Zmerli, supra note 133, at 635. If this hypothesis proves true, it would muddy any neat relationship between law and social trust. Laws that are successful at creating social trust might ultimately lessen norms of law-abidingness which, over time, would reduce laws' efficacy, both functionally and in promoting trust.

${ }^{255}$ See Rose, supra note 29 , at 44.

${ }^{256}$ See id.; Dagan \& Heller, supra note 130, at 596. 
More controversially, however, I suggest that high bonding social capital may necessitate laws to limit, diffuse, or deconstruct residential social capital (particularly when law cannot directly reach social capital harms due to its design or enforcement, or when the costs of exit are high). ${ }^{257}$ Alternatively, building social capital within a greater number of distinct groups (that is, pluralism) has potential to lessen dark side dynamics; however, this does not translate well to the context of homogenous localities and the harms that spillover to groups outside the local political process. This point underscores the importance of the level of government that is involved. Depending on the particular issue and circumstances, negative social capital dynamics may benefit from legal controls at different levels of government (for instance, there is little incentive for localities that gain from an exclusionary practice to adopt laws restraining it, and intervention must come from federal or state government). In some cases, swift legal intervention may be important to subdue negative social capital dynamics before they spiral - and before participants capture the political process. With respect to residential self-governance, formal law can mitigate illiberalism by providing frameworks and rule infrastructure that lessen the cost of coordination and cooperation, as well as the attendant pressures toward homogeneity and status-based allocations. Legal institutions can also reduce "diversity anxiety" by providing rules, safeguards, and supports that signal rule of law values and opportunities for recourse.

Addressing social capital harms requires a variety of legal tools, including direct restrictions, political process safeguards or correctives, incentives, and, in some instances, use of thicker institutions rather than informal self-governance. Co-governance where groups manage property within a substantial framework of state-created law and oversight offers one intermediate solution to the problems of governing residential property through social capital (notably, the much-vaunted commons of the lobster gangs and fisheries have moved to co-governance and collaborative resource management with state and federal government). ${ }^{258}$ Concededly, legal design often strays from the optimal. Peter Schuck's work has examined the tendency of law to be heavy-handed, costly and

\footnotetext{
${ }^{257}$ Social capitalists also do not address whether high social capital should remain a goal in contexts where the scope of law or meager enforcement does not reach social-capital driven harms.

${ }^{258}$ See, e.g., James M. Acheson, Capturing the Commons: Devising Institutions to Manage the Maine Lobster Industry 97-101 (2003).
} 
inefficient, reductionist due to the need for simple categorizations, and biased in favor of powerful interests or the status quo. ${ }^{259} \mathrm{He}$ also describes the shortcomings and unintended consequences of aggressive diversity programs. ${ }^{260}$ While I acknowledge the variable quality of law, there are certainly legal frameworks that function effectively (that is, more efficiently than no law). Indeed, well designed laws often fade to the background precisely because they are working quietly and efficiently.

Some scholars have argued that law is at odds with social capital and trust. Larry Ribstein asserts that law can discourage trust-creating social capital in private and business associations by creating monitoring obligations and reducing exclusivity. ${ }^{261}$ Putnam's work at times views law as a sign of crumbling social capital rather than an independent, positive social good. ${ }^{262}$ Yet, laws protecting individual rights and community flourishing are not inevitably at odds. Robert Post describes how tort, privacy, and other laws often simultaneously protect community and individuals by protecting essential community norms that constitute both individuals and society. ${ }^{263} \mathrm{He}$ observes that the interdependency between individuals and community "makes possible a certain kind of human dignity and autonomy that can exist only within the embrace of community norms. ${ }^{264}$ In residential property, law and legal debate have often vacillated in a binary fashion between community interests and individual rights. ${ }^{265}$ Perhaps properly understood, laws that safeguard individual rights against the excesses of social capital also protect community, both local territorial communities and broader communities of interest.

${ }^{259}$ See Peter H. Schuck, The Limits of Law: Essays on Democratic Governance 4-6, 16 17,428 (2000) (examining costs of legal complexity and the inefficiencies of blunt legal categorization); Peter H. Schuck \& Richard J. Zeckhauser, Targeting in Social Programs 46-49, 131-33 (2006) (discussing problematic legal distributions and policy inefficiencies from bad bets).

${ }^{260}$ Peter H. Schuck, Diversity in America: Keeping Government at a Safe Distance 58-61, 186, 309-11 (2003).

${ }^{261}$ See Larry E. Ribstein, Law v. Trust, 81 B.U. L. Rev. 553, 584 (2001).

262 Putnam, supra note 2, at 144-47.

${ }^{263}$ Robert C. Post, Constitutional Domains 62-64 (1995).

${ }^{264}$ See id. at 51.

${ }^{265}$ For example, some of the discourse over residential exclusion has framed harms in terms of individual injuries and rights, with lesser attention to harms to communities, either local or national. See, e.g., Jonathan Kaplan \& Andrew Valls, Housing Discrimination as a Basis for Black Reparations, 21 Pub. Aff. Q. 255, 265-69 (2007); Margery Austin Turner, Limits on Housing and Neighborhood Choice: Discrimination and Segregation in U.S. Housing Markets, 41 Ind. L. Rev. 797, 809-13 (2008). 


\section{A. Political Organizing, Low-Income Communities, and Social Capital}

One objection to my account is whether there is a better case for promoting social capital to support political organizing, particularly in lowincome communities that cannot afford substitutes for social capital (for instance, private security and services). Barriers to organizing, including low social capital, have undeniably disadvantaged low-income communities in the political process. ${ }^{266}$ Yet, it is questionable whether the target of this Article, insular bonding social capital promoted through residential law, is a critical precursor of political organizing for poor neighborhoods. Dense and strong social ties and norms of reciprocity, key elements of social capital, are often present in disadvantaged communities. ${ }^{267}$ Notably, research shows that such social capital can create networks that integrate criminals into communities and lessen the regulatory effect of neighborhood social cohesion and norms of social control on crime. ${ }^{268}$ If low-income communities must bolster social capital, developing it through participation in public institutions or bridging ties that draw citizens into broader political communities may be more beneficial than promoting neighborhood bonding capital. ${ }^{269}$

The skills of organizing and institution-building, or agents with these qualities, may be what is most important to political participation. ${ }^{270}$ As Part III illustrates, residential self-governance does not reliably develop residents' institution-building capacities (and if it did, a question would remain whether self-governance reduces the time, energy, and social capital available for political organizing). Findings by Robert Sampson underscore the important role of leaders and agents. ${ }^{271}$ The penetration

\footnotetext{
${ }^{266}$ See generally Kay Lehman Schlozman et al., The Unheavenly Chorus: Unequal Political Voice and the Broken Promise of American Democracy (2012).

${ }^{267}$ See Christopher R. Browning et al., The Paradox of Social Organization: Networks, Collective Efficacy, and Violent Crime in Urban Neighborhoods, 83 Soc. Forces 503, 523 (2004).

${ }^{268}$ See id. at 523-24 ("While networks promote neighborhood cohesion and informal social control orientations, they also generate network-based social capital ... that may inhibit more consequential forms of social control."); Sudhir Alladi Venkatesh, The Social Organization of Street Gang Activity in an Urban Ghetto, 103 Am. J. Soc. 82, 95-97 (1997) (finding that dense and strong social ties lessened support for efforts to rid neighborhood of gangs); cf. Mary Pattillo-McCoy, Black Picket Fences 69-70 (1999) (reporting similar findings in study of middle-income black Chicago neighborhood).

${ }^{269}$ Cf. Sampson, supra note 36.

${ }^{270}$ I thank Henry Hansmann for his insights on this point.

${ }^{271}$ See Sampson, supra note 36, at 348, 369-70 (studying the effect of urban leadership structures and the social networks that connect leaders within communities).
} 
of non-profit organizations, not strong and dense ties, predicts community collective action (for instance, protests, fundraisers, and neighborhood events). ${ }^{272}$ Social capital is not absent from this process (a common vocabulary, minimal baseline of trust, and social networks help), but it is not front and center. Research is just beginning to determine which types of institutions produce positive outcomes in low-income communities. Some of this scholarship can appear partisan, with proponents arguing for favored institutions. ${ }^{273}$ Rather than micro-level social engineering, it may be more beneficial to bluntly subsidize non-profit institutions and allow politics, donations, and social forces to roughly sort out valuable institutions for individual communities.

\section{B. The Social Production of Neighborhood and Individual Capacity}

Retreat from local social capital building may be problematic if high social capital or property self-governance is critical to the social production of neighborhoods or the identity of residents. In some instances where we find solidarity and social capital most appealing, the non-market or non-legal nature of the interaction is critical to the production of social units and identities, such as family, friend, or congregation. For example, Bob Ellickson's writing on social norms within the family recognizes norms against monetization of services and contracting within the household as important to the social construction of the household, as well as efficient. ${ }^{274}$ Similarly, hiring a professional PTA would not be an effective substitute for a parent-led school association. Much of the value of the PTA is that children observe their parents' participation and infer the value of education.

Promoting local social capital or informal governance of residential property does not appear comparably important to producing the social unit of the neighborhood or individual identities. ${ }^{275}$ Most people rely on nonterritorial communities for a sense of community and strong social

\footnotetext{
${ }^{272}$ See id. at $214-17$.

${ }^{273}$ See Brinig, supra note 17, at 887 (advocating for Catholic schools); Fischel, supra note 17 , at 113 (advocating for traditional local public schools and against a school voucher system).

${ }^{274}$ See Robert C. Ellickson, The Household: Informal Order Around the Hearth 28-29, 102-06 (2008).

${ }^{275}$ I thank Amy Kapczynski for her helpful questions about the role of property in producing identities.
} 
ties. ${ }^{276}$ For example, in response to the survey question, "what are the ways in which you get a real sense of belonging or sense of community," over seventy percent of respondents cited family and non-neighbor friends. ${ }^{277}$ Decades of research establish that neighborhoods are characterized by weak ties and residents have on average only a handful of strong friendship ties in their community - and that they prefer it this way. ${ }^{278}$ Even ethnic enclaves, long idealized in academia, serve primarily as way-stations that help new immigrants gain economic footing, at which point they often depart. ${ }^{279}$ My claim here is not that the neighborhood-particularly resident involvement in local schools or organizations - invariably lacks meaning. It is that in view of the comparatively weak construct of neighborhood and the organic social capital already present in communities, retreat from promoting social capital is unlikely to threaten individual or neighborhood identity. Moreover, indiscriminately devolving governance and public goods provision to residents appears as likely to harm as to benefit any communal social meaning vested in neighborhoods by breeding conflict. ${ }^{280}$

What about the role of social capital and collective action in developing individual capacities? This theory traces to John Stuart Mill's asser-

${ }^{276}$ See Avery M. Guest \& Susan K. Wierzbicki, Social Ties at the Neighborhood Level: Two Decades of GSS Evidence, 35 Urb. Aff. Rev. 92, 103 (1999). Data averaged across the period of 1974-1996 reveal that more than one-quarter of respondents never spent a social evening with neighbors, approximately $15 \%$ spent a social evening with neighbors once a month, and approximately $12 \%$ several times a month. See id. at 99 tbl.1. The amount of socializing with friends is nearly double. See id. The comparatively weak attachment to neighborhood and community is also reflected in the mobility data with homeowners reporting a median stay of only 8.2 years in each residence. See William M. Rohe et al., The Social Benefits and Costs of Homeownership: A Critical Assessment of the Research 13 (Joint Ctr. for Hous. Studies of Harvard Univ., Working Paper No. LIHO-01.12, 2001), available at http://www.jchs.harvard.edu/sites/jchs.harvard.edu/files/liho01-12.pdf.

${ }^{277}$ See Putnam, supra note 2, at 274, 275 fig.77. One-third or less of respondents cited local community or neighbors. See id.

${ }^{278}$ The average person has approximately a dozen strong social ties but only two or three of those ties are to neighbors. See I-Neighbors Encourages Local Bonds, MIT Tech Talk 3, 3 (2004), available at http://web.mit.edu/newsoffice/2004/techtalk49-1.pdf ; see also Sampson, supra note 36, at 170-71 (noting how people desire trust with their neighbors but not necessarily thick ties); Stephanie M. Stern, Residential Protectionism and the Legal Mythology of Home, 107 Mich. L. Rev. 1093, 1122-24 (2009) (reviewing literature on weak ties in residential communities).

${ }^{279}$ Notably, recent demographic trends show that more immigrants are settling directly in the suburbs rather than gateway cities. See Marie Price \& Lisa Benton-Short, Migrants to the Metropolis 19 (2008).

${ }^{280}$ See, e.g., supra Section III.A-B. 
tion that voluntary action educates citizens socially and democratically, producing happier, more thoughtful and civic-minded individuals. ${ }^{281}$ My analysis demonstrates more variable outcomes from group engagement in residential settings. Voluntary action at times can produce illiberal exclusion and collusive activity that provides an anti-social education. ${ }^{282}$ Even ostensibly positive or pro-social participation, such as serving on one's condominium board, frequently results in citizen-participants departing frustrated or demoralized, rather than brimming with civic gravitas. There is also no evidence that private-regarding residential norms and local collective action (or collusion) create trust, goodwill, or prosocial motivations that enable generosity or wealth redistribution in other, non-residential contexts. The research on self-preferencing in-groups, as well as social capital's claim that local cooperation delivers national dividends, give us little reason to anticipate that extra-local altruistic behavior will spring from residential solidarity. ${ }^{283}$

Even the evidence for increased happiness from social capital is thin. In the Community Benchmark survey, Putnam reports that higher social capital correlates with greater happiness and community satisfaction. ${ }^{284}$ However, this finding is subject to reverse causation, meaning that perhaps happier people are more likely to participate in activities, trust others, and possess social ties that would yield high social capital scores. A well-established body of research on happiness also undermines a continuous positive relationship between social capital and happiness: while social ties are important to happiness, people are highly individualized in the amount of socializing they require, and many are happy with a relatively small number of satisfying relationships ${ }^{285}$ In addition, some of the sociological research suggests that solidaristic communities can be quite unhappy places for the successful who are burdened by requests for favors, loans, and jobs. ${ }^{286}$

\footnotetext{
${ }^{281}$ See John Stuart Mill, On Liberty and Other Essays 121 (John Gray ed., 1991).

${ }^{282}$ See supra Part II.

${ }^{283}$ See supra note 33 and accompanying text.

${ }^{284}$ See The Saguaro Seminar: Civic Engagement in America, Social Capital Community Benchmark Survey Executive Summary 1, 7 (2001), http://www.hks.harvard.edu/saguaro/ communitysurvey/docs/exec summ.pdf.

${ }^{285}$ See, e.g., John T. Caccioppo \& William Patrick, Loneliness: Human Nature and the Need for Social Connection 94 (2008).

${ }^{286}$ See Portes, supra note 25, at 16.
} 


\section{Alternatives for Generalized Solidarity}

Do property gemeinschafts and social capital encourage a valuable sense of solidarity that may be otherwise lacking in modern society? Solidarity may bind citizens together with shared purpose and mission and encourage social contribution, redistribution, and individual and national flourishing. Putnam's bridging social capital tracks the concept of broad, cross-cutting solidarity. ${ }^{287}$ Without platforms for solidarity, collective identity may founder and endanger collective action, democratic participation, and the polity. At the extreme, a society may develop anomie, where the collective conscience frays and norms and moral regulation no longer check individual appetites and ambitions. ${ }^{288}$

I am dubious of the threat of anomie or other solidarity harms from more limited residential self-governance or decreased local social capital-building initiatives (assuming such efforts are even effective at creating social capital). First, other institutions, such as religion, schools, and the workplace, appear at least as central, and likely more, to moral norms and collectivism than residential property. ${ }^{289}$ Within the residential context, it is not evident that greater social distance and less dense social ties threaten normlessness or anomie. At the larger residential scale of cities, people rely on norms and shared moral conceptions to navigate communities and coordinate interactions under conditions of high population density and relative anonymity. For example, city residents develop widely understood norms to govern such issues as street parking, queues, and behavior in public spaces - these norms have socializing as well as communicative value. ${ }^{290}$

Second, there are other, more encompassing forms of solidaritytight-knit localism is not the only option. Retreating from local solidarity

\footnotetext{
${ }^{287}$ See Putnam, supra note 2, at 22-24.

${ }^{288}$ See Emile Durkheim, The Division of Labor in Society 304-08 (1984) (describing anomie as an unusual and pathological social condition resulting from sudden economic or social change).

${ }^{289}$ See, e.g., supra Section V.B. Also, the narrative that diversity may threaten moral regulation and norms is questionable in the residential context if laments about the alienation and social competition in homogenous American suburbs have any truth. See The Evolution of Home Ownership, HomeInsight, http://www.homeinsight.com/details.asp?url_id=7 (last visited Mar. 7, 2013). Durkheim recognized the point that mechanical solidarity and greater similarity can increase competition at least in the economic sense. See Durkheim, supra note 288 , at 210 .

${ }^{290}$ See, e.g., Carol M. Rose, Possession as the Origin of Property, 52 U. Chi. L. Rev. 73, 81 (1985) (describing the practice of reserving shoveled parking spaces on public streets with chairs as clearly communicating property claims).
} 
may redirect political energy and identity outward and strengthen these broader forms of solidarity. Scholars from a variety of disciplines have described alternatives to gemeinschaft solidarity. Durkheim conceptualized "organic societies" based on complex, interdependent roles within society with strong norms associated with the roles. ${ }^{291}$ Building on this foundation, Portes and Vickstrom define organic solidarity as "universalistic rules and their embodiment in specific roles." ${ }^{292}$ The interdependencies and specialization in organic society promote cohesion and cooperation that secure solidarity. ${ }^{293}$ In a similar vein, Max Weber described bureaucracies as centralized, hierarchical organizations bound together by rational laws, specialization in individual tasks and bureaucratic structure, and the demands of the tasks to be accomplished (although as Daniel Kreiss notes these ideals "rarely function in the real world as they do on paper"). ${ }^{294}$

Solidarity may also come from common commitments or shared morals. Drawing from Aristotelian thought, philosopher Alasdair MacIntyre writes of the shared moral community. ${ }^{295}$ Multiculturalism theorists suggest that shared values, history, and enthusiasm for "deep diversity" may, if not create, at least sustain broader social solidarity. ${ }^{296}$ Generalized trust, or the belief that strangers can be trusted, binds societies together. ${ }^{297}$ And the sociological theory of professionalism describes the development of the professional role and its normative focus on universalistic standards of science and expertise, service to the community, and

\footnotetext{
${ }^{291}$ See Durkheim, supra note 288, at 132-33.

${ }^{292}$ See Portes \& Vickstrom, supra note 88 , at 473 . In more recent writing, task solidarity across the military has emerged as an argument for how the military can preserve solidarity in the face of heterogeneity of sexuality. See Gregory Herek, Unit Cohesion and the Military Mission, http://psychology.ucdavis.edu/rainbow/html/military_cohesion.html (last visited Mar. 7, 2013).

${ }^{293}$ See Durkheim, supra note 288, at 104-05.

${ }^{294}$ See Max Weber, Economy and Society 956, 973-75 (Univ. of Cal. Press 1978); see also Daniel Kreiss et al., The Limits of Peer Production: Some Reminders from Max Weber for the Network Society, 13 New Media \& Soc'y 243, 249 (2011).

${ }^{295}$ See, e.g., Alasdair MacIntrye, After Virtue 251-54, 258 (1984) (criticizing Enlightenment individualism and advocating a return to the Aristotelian tradition of socially understood virtue and a shared vision of morality).

${ }^{296}$ See Will Kymlicka, Multicultural Citizenship 188-91 (1995) (discussing theories of social unity for polyethnic and multi-nation states).

${ }^{297}$ See Dietlind Stolle, Trusting Strangers-The Concept of Generalized Trust in Perspective, 31 ÖZP 397, 397-99 (2002), available at http://www.oezp.at/pdfs/2002-4-02.pdf (defining and discussing generalized trust).
} 
service-delivery rather than the identity of the client. ${ }^{298}$ Although some aspects of the professional role appear overstated, professionalism does create commonality among professionals as well as between professionals and clients through the norm of impartial service-provision.

Stepping back, each of these theories is a form of generalized solidarity, by which I mean a form of solidarity that extends beyond one's immediate group or territorial enclave. The source of generalized solidarity in the accounts above varies between intensive social interdependencies and universal, or at least broadly shared, norms, morals, or trust. For my purposes, the point is not to endorse one choice but rather to discuss alternative sources of solidarity that sound not only in one's community but also in society more broadly. In the residential property setting, the specific forms of generalized solidarity available vary by context, and even geography, and multiple forms overlap and reinforce one another. Admittedly, there is still much to learn about building generalized solidarity and I don't claim that generalized solidarity will reliably trump bonding capital (thought it may lessen its harms and convey other benefits to residential life). Rather, my claim is that generalized solidarity is available to forestall any descent into anomie or normlessness. ${ }^{299}$

Interestingly, open property markets themselves can be one form of generalized solidarity - though not the most broadly inclusive or necessarily the most desirable. Eighteenth-century economic writers described a "gentle commerce" that brings people together and forces them to consider and account for the interests of far-flung others in order to trade..$^{300}$ Carol Rose has posited a socializing role of property, writing about how property markets can place people into contact with others far from their geographic home and social niche and inculcate norms and trust. ${ }^{301}$ To extend these ideas, it may be that property has the capacity not only to socialize but also to help develop generalized solidarity by structuring open markets and even playing fields of rules for participants to inter-

\footnotetext{
${ }^{298}$ See Bryan S. Turner, Talcott Parsons, Universalism and the Educational Revolution: Democracy Versus Professionalism, 44 Brit. J. Soc. 1, 14 (1993).

${ }^{299}$ I have previously discussed the fact that alternative forms of solidarity or bridging ties do not remedy or trump the dark side of local capital. In this section, my point is different: alternative forms of solidarity hold other values for society and can substitute for any reductions in local social capital.

${ }^{300}$ Carol M. Rose, Whither Commodification?, in Rethinking Commodification 402, 419 (Martha M. Ertman \& Joan C. Williams eds., 2005).

${ }^{301}$ Id. at 402, 412-13, 419 (describing how imperfect information can encourage dense social networks, long-term relationships, and more complex social structures).
} 
act. ${ }^{302}$ Indeed, this may be part of the intensely negative reaction to practices such as mortgage lending discrimination and redlining, which not only impose individual harms but also sully the universalizing rules of the market. The dark side of residential social capital offers a fresh perspective on the longstanding debate about market commodification and alienation. ${ }^{303}$ Upon closer view, legal and market institutions may play a larger socializing and liberalizing role in residential property than perceived by social capital exponents. And residential social capital, despite its cheerful mantle of sociability, can assume anti-social, factional, and illiberal forms.

\section{CONCLUSION}

Social capital has beguiled property law with its claims of efficiency and self-governance through sociability and territorial cooperation. The enthusiasm for social capital has obscured its costs and tradeoffs to property markets, governance, and residential diversity. This Article offers a fuller accounting of the dark side of local social capital and its capacity to close off residential property. I contend that we should be skeptical of social capital's primacy to property institutions (and vice versa), realistic about its benefits, and cognizant of its capacity for harm. And if social capital, and correspondingly my account of its dark side, proves too nebulous to gain traction on property issues, we must turn from social capital and direct legal responses to context-specific harms and benefits.

\footnotetext{
${ }^{302}$ Allport's seminal theory of optimal conditions shows that lessening prejudice and ingroup bias through contact, or integration, requires that participants interact on a relatively level playing field of status, goals, norms, and laws. Gordon W. Allport, The Nature of Prejudice $250-55,267$ (1958).

${ }^{303}$ See Margaret Jane Radin, Market-Inalienability, 100 Harv. L. Rev. 1849, 1870 (1987) (expressing concern about the commodifying and anti-social nature of markets).
} 